\title{
SAVJETOVANJE S JAVNOŠĆU U PRIPREMI PROPISA U HRVATSKOJ
}

DOI: $10.3935 / z p f z .70 .23 .08$

Prethodno znanstveno priopćenje

Primljeno: travanj 2020.

Savjetovanje s javnošću uobičajen je instrument uključivanja javnosti u procese oblikovanja javnih politika diljem demokratskih država, koje ih najčešće pravno reguliraju. U Republici Hrvatskoj savjetovanja s javnošću - osobito u svojoj elektroničkoj inačici (e-savjetovanja) - predstavljaju relativno nov način participacije javnosti u procesu regulacije, koji znanstveno još nije opsežnije istražen. U ovom se radu savjetovanja s javnošću analiziraju u dva aspekta. Prvo, ocjenjuje se adekvatnost hrvatskog pravnog okvira te se ocjenjuje njegova uskladenost s međunarodnim standardima, dok se u drugom dijelu prikazuju nalazi empirijskog istraživanja provedenog metodom kvantitativne analize sadržaja izvješća i drugih dokumenata e-savjetovanja koja su provele upravne organizacije u Hrvatskoj u razdoblju od 2016. do 2018. godine.

Ključne riječi: savjetovanja s javnošću, pravni okvir, primjena e-savjetovanja, upravne organizacije, empirijsko istraživanje

\section{UVOD}

Savjetovanja s javnošću uvriježen su i, u praksi brojnih demokratskih zemalja, jedan od najčešće korištenih instrumenata uključivanja javnosti u oblikovanje propisa i javnih politika, tj. u regulativnu funkciju uprave. Riječ je o alatu za prikupljanje mišljenja, primjedbi i sugestija fizičkih i pravnih osoba na nacrte propisa, općih akata i planskih dokumenata od strane upravnih i drugih tijela

* Dr. sc. Petra Đurman, poslijedoktorandica Pravnog fakulteta Sveučilišta u Zagrebu, Trg Republike Hrvatske 14, 10000 Zagreb; pdurman@pravo.hr;

ORCID ID: orcid.org/0000-0002-8287-3686 
javne vlasti, koja odlučuju i obrazlažu prihvatljivost upućenih prijedloga. Iako savjetovanja s javnošću nisu uvijek predmet pravnih propisa (već se može raditi o političkoj odluci da se javnosti omogući utjecaj na donošenje odluka, preuzimanju dobrih praksi i sl.) $)^{1}$ u većini demokratskih država savjetovanja su danas regulirana mehanizmima tvrdog (zakonom ili čak ustavom) ili mekog prava (preporukama, smjernicama), sustavno ili u određenim sektorskim područjima, odnoseći se na primarno ili sekundarno zakonodavstvo ili na oboje. Na razini Europske unije (EU) sve države članice reguliraju provedbu savjetovanja s javnošću - kao obvezatnu proceduru ili preporuku tijelima javne vlasti - iako uz značajne varijacije u opsegu i sadržaju zahtjeva (u pogledu informiranja javnosti, trajanja savjetovanja, vrste i opsega popratnih dokumenata koji se objavljuju, povratne informacije javnosti, tehnika savjetovanja). Varijacije u pravnoj regulaciji, zajedno s ustaljenim praksama i tradicijom upravnih sustava pojedinih zemalja, dovode do razlika u njihovoj primjeni. Usprkos tome, evidentno je postojanje pozitivnog trenda - online savjetovanja s javnošću (najčešće putem jedinstvenih portala) postaju imperativ provedbe i domena kontinuiranog tehnološkog napretka, kao posljedica općeg napretka informacijsko-komunikacijske tehnologije (IKT) u suvremenom društvu. S druge strane, moguće je uočiti negativan izazov u nedostatku sustavnih evaluacija procesa savjetovanja i njihovih ishoda od strane organizatora, akademske zajednice, stručnih udruženja i dr. ${ }^{2}$

U Republici Hrvatskoj (RH) savjetovanja s javnošću najprije su uvedena Kodeksom savjetovanja sa zainteresiranom javnošću u postupcima donošenja zakona, drugih propisa i akata ${ }^{3}$, koji je Vlada usvojila 2009. godine. Do kvantitativnog pomaka u njihovoj provedbi došlo je nakon donošenja Zakona o pravu na pristup informacijama ${ }^{4}$ 2013. godine, kojim su savjetovanja postala obvezatna procedura za tijela javne vlasti u donošenju akata kojima se utječe na interese

1 Instrumenti participacije javnosti oživotvorenje su načela otvorenosti, koje je vezano uz procese političkog odlučivanja i političke moći, za razliku od ostvarivanja načela transparentnosti primarno kroz pravni instrument pristupa informacijama tijela javne vlasti. Vidi Musa, A., Transparentnost - kako i zašto?, u: 5. Forum za javnu upravu, Institut za javnu upravu i Friedrich Ebert Zaklada, Zagreb, 2013., str. 11; Musa, A., Informacije za građane: transparentnom i otvorenom javnom upravom prema boljem upravljanju i povjerenju građana, u: Koprić, I.; Musa, A.; Giljević, T. (ur.), Gradani, javna uprava i lokalna samouprava: povjerenje, suradnja, potpora, Institut za javnu upravu, Zagreb, 2017., str. 29 - 72.

2 Vidi, primjerice, Pina, V.; Torres, L., The Managers' View of Participation Processes with Citizen Panels, u: Aichholzer, G.; Kubicek, H.; Torres, L. (ur.), Evaluating e-Participation: Frameworks, Practice, Evidence, Springer, London, 2016., str. 301.

3 Narodne novine, br. 140/2009.

4 Narodne novine, br. 25/2013, 85/2015. 
javnosti. Izmjene Zakona 2015. godine, uz preciziranje odredbe članka 11. kojim su uređena savjetovanja, pratile su uvođenje jedinstvenog portala za elektronička (e-)savjetovanja za upravne organizacije na državnoj razini i druga državna tijela, čime je počela i nova faza njihove provedbe, ponajprije u sadržajnom smislu (kvaliteta savjetovanja). Prema izvješću OECD-a o praksama bolje regulacije u članicama EU-a ${ }^{5}$, Hrvatska se u pojedinim aspektima regulacije savjetovanja izdvaja dobrim praksama koje dijeli manji broj članica EU-a - objavljivanje godišnjih planova savjetovanja, transparentnost uključivanja zainteresirane javnosti u izradu podzakonskih propisa te postojanje formalnih mehanizama nadzora nad provedbom savjetovanja. Međutim, budući da je riječ o relativno novom instrumentu čije značajke i učinci u praksi nisu znanstveno značajnije istraženi, čini se važnim steći dublji uvid u način na koji se zakonske odredbe primjenjuju u praksi.

Cilj je ovog rada dvostruk: (i) analizirati pravni okvir za savjetovanja s javnošću u Hrvatskoj i ocijeniti njegovu usklađenost s međunarodnim standardima te (ii) analizirati provedbu savjetovanja u praksi upravnih organizacija na temelju empirijskih podataka. U nastavku rada slijedi sadržajno određenje savjetovanja s javnošću kao jednog od instrumenata participacije javnosti u procesu regulacije (2.). Treće poglavlje sadržava pregled zakonodavnog okvira za savjetovanja s javnošću u Hrvatskoj (3.1.) te ocjenu usklađenosti hrvatskog normativnog okvira s međunarodnim standardima (3.2.). U četvrtom dijelu analizira se provedba savjetovanja s javnošću u praksi hrvatskih upravnih organizacija, najprije na temelju sekundarnih izvora podataka (4.1.), a zatim na temelju nalaza empirijskog istraživanja provedenog metodom kvantitativne analize sadržaja izvješća o e-savjetovanjima (4.2.). Naposljetku se raspravlja o glavnim nalazima istraživanja i daju se zaključna razmatranja uz navođenje praktičnih preporuka za provedbu e-savjetovanja u Hrvatskoj (5.).

\section{SAVJETOVANJA S JAVNOŠĆU KAO INSTRUMENT PARTICIPACIJE JAVNOSTI U PROCESU REGULACIJE}

Uključivanje javnosti u donošenje odluka i oblikovanje javnih politika danas je nužna značajka suvremenih demokratskih država. ${ }^{6}$ Suočene sa sve komplek-

5 OECD, Better Regulation Practices across the European Union, OECD Publishing, Paris, 2019., http://www.oecd.org/publications/better-regulation-practices-across-the-european-union-9789264311732-en.htm (30. ožujka 2020.).

6 O promijenjenom odnosu vlasti, uprave i građana u suvremeno doba vidi Koprić, I., Demokracija, decentralizacija, povjerenje građana i ponos javnih službenika: stari i novi 
snijim javnim problemima i slabim povjerenjem građana, funkcioniranje javne uprave u sve većoj mjeri polazi od načela transparentnosti, otvorenosti i responzivnosti prema javnosti. Njihovo oživotvorenje pretpostavlja niz instrumenata koji se mogu primjenjivati na različitim razinama vlasti, u različitim sektorskim područjima, tijekom različitih faza procesa stvaranja javnih politika (od postavljanja pitanja na dnevni red do evaluacije, no najčešće tijekom oblikovanja javnih politika), a koji se razlikuju prema razini angažmana i utjecaja javnosti. Uključivanje javnosti nije samo "imperativ za legitimitet" propisa, politika i njihove provedbe nego i vrlo praktična, racionalna stvar s gledišta uprave, s obzirom na to da može unaprijediti kvalitetu propisa i olakšati njihovu provedbu.

Kada je riječ o uključivanju javnosti u oblikovanje propisa i politika, u literaturi je uvriježena podjela na tri razine koje odražavaju stupanj angažmana i mogućnost utjecaja javnosti. Prva je razina informiranje (javno komuniciranje) koje podrazumijeva jednosmjeran tijek informacija od donositelja odluka prema javnosti, bez povratnog tijeka informacija od strane javnosti. Konzultiranje kao viša razina omogućuje prijenos informacija i u suprotnom smjeru, ali bez postojanja dijaloga, partnerskog odnosa i mogućnosti predlaganja dnevnog reda od strane javnosti, koje su značajke participacije kao treće, najviše razine uključivanja. ${ }^{8}$ Razina konzultiranja uključuje niz konkretnih instrumenata koji se mogu primjenjivati u praksi, od kojih su savjetovanja s javnošću (javna savjetovanja, konzultacije ili rasprave) jedan od najčešće korištenih.?

Savjetovanje s javnošću podrazumijeva da tijelo javne vlasti javno objavljuje nacrt normativnog akta i poziv javnosti da izrazi svoje mišljenje odnosno dostavi povratnu informaciju o predloženom aktu. To je zajedničko obilježje svih savjetovanja, a ono po čemu se razlikuju su tehnike objavljivanja nacrta akata i prikupljanja povratne informacije javnosti. Pritom tijelo javne vlasti uvijek određuje način na koji će se prikupljati primjedbe i prijedlozi zainteresiranih

koncepti u razvoju odnosa građana i javne uprave, u: Koprić, I.; Musa, A.; Giljević, T. (ur.), Gradani, javna uprava i lokalna samouprava: povjerenje, suradnja, potpora, Institut za javnu upravu, Zagreb, 2017., str. $4-7$.

7 Wang, X.; Wan Wart, M., When Public Participation in Administration Leads to Trust: An Empirical Assessment of Managers' Perceptions, Public Administration Review, vol. 67, br. 2, 2007., str. 266.

8 OECD, Građani kao partneri: Informiranje, konzultiranje i participiranje javnosti u kreiranju provedbene politike, Oksimoron, Zagreb (hrvatski prijevod), 2004., str. 24; Rowe, G.; Frewer, L. J., A Typology of Public Engagement Mechanisms, Science, Technology \& Human Values, vol. 30, br. 2, 2005., str. 255 - 256.

9 Primjeri drugih instrumenata uključuju radne skupine i savjetodavne odbore, ispitivanja mnijenja građana, panele građana, fokus grupe i sl. 
dionika. Javnost može svoje stavove izraziti usmeno, ako se savjetovanje organizira kao vrsta javnog okupljanja, te pisanim putem slanjem komentara poštom, e-poštom ili putem posebnog mrežnog portala. Stoga, moguće je razlikovati offline i online oblike savjetovanja. U novije vrijeme razvoj modernog IKT-a omogućio je etabliranje internetskih savjetovanja kao standarda provedbe, iako se još koriste tradicionalne javne rasprave $\mathrm{u}$ obliku javnog prezentiranja nacrta akta od strane upravnih službenika, pri čemu je javnost pozvana postavljati pitanja i davati komentare (na lokalnoj razini). Prednosti online savjetovanja uključuju veću transparentnost oblikovanja propisa, mogućnosti šireg uključivanja javnosti te potencijalno veću razinu interaktivnosti s obzirom na to da online komuniciranje briše različite vizualne prepreke među sudionicima (fizičke, socioekonomske i dr.), dok su potencijalni problemi vezani uz problem digitalne podjele - povećavanje postojećih nejednakosti u društvu ili stvaranje novih podjela. ${ }^{10}$

Savjetovanja s javnošću predmet su akata i dokumenata EU-a i drugih međunarodnih organizacija (Vijeće Europe, UN, OECD), a na nacionalnoj razini najčešće su regulirana zakonom ili neobvezujućim smjernicama. Općenito govoreći, u anglosaksonskim i skandinavskim zemljama prevladava pristup mekog prava, dok je u europskim kontinentalnim zemljama evidentniji tvrdi pristup $^{11}$, uz značajne razlike među pojedinim državama i manjak sustavne regulacije savjetovanja. ${ }^{12}$

10 Tomkova, J., E-consultations: New tools for civic engagement or facades for political correctness?, European Journal of ePractice, br. 7, 2009., str. 3 - 6, http://citeseerx.ist. psu.edu/viewdoc/download?doi=10.1.1.466.7291\& rep=repl\&type $=$ pdf $(3$. siječnja 2020.); Fuchs, D., Participatory, liberal and electronic democracy, u: Zittel, T.; Fuchs, D. (ur.), Participatory Democracy and Political Participation: Can participatory engineering bring citizens back in?, Taylor i Francis, New York, 2007., str. 42 - 44; Shulman, S. W., eRulemaking: Issues in Current Research and Practice, eRulemaking Research Group, 2005., str. 635, https://scholarworks.umass.edu/erulemaking/4 (3. siječnja 2020.).

11 Bugarič, B., Openness and Transparency in Public Administration: Challenges for Public Law, Wisconsin International Law Journal, vol. 22, br. 3, 2004., str. 505 - 506; vidi Popelier, P., Management of Legislation, u: Karpen, U.; Xanthaki, H. (ur.), Legislation in Europe: A Comprehensive Guide for Scholars and Practitioners, Hart Publishing, Oxford, Portland, 2017., str. 57 - 59. 


\section{PRAVNI OKVIR ZA PROVEDBU SAVJETOVANJA S JAVNOŠĆU U RH I NJEGOVA USKLAĐENOST S MEĐUNARODNIM STANDARDIMA}

\subsection{Pravni okvir za savjetovanja s javnošću u RH}

Ustav $\mathrm{RH}^{13}$ postavlja temeljna načela normiranju participacije građana $\mathrm{u}$ drugim zakonima i propisima, no ne uređuje izravno pitanje savjetovanja s javnošću. Ustavni sud ima ulogu u etabliranju standarda i načela demokratičnosti procedure donošenja propisa, što je potvrdio 2013. ukinuvši dva podzakonska akta Ministarstva znanosti, obrazovanja i sporta ${ }^{14}$ zbog izostanka adekvatne procedure $\mathrm{u}$ pogledu uključivanja svih zainteresiranih dionika u postupak njihove izrade. Savjetovanja s javnošću regulirana su primarno Zakonom o pravu na pristup informacijama (ZPPI $)^{15}$, koji sadržava temeljne obvezujuće odredbe općeg režima savjetovanja, i Kodeksom savjetovanja sa zainteresiranom javnošću u postupcima donošenja zakona, drugih propisa i akata ${ }^{16}$, koji to čini na razini pravno neobvezujućeg mehanizma. Od ostalih horizontalnih propisa ${ }^{17}$ Zakon

13 Ustav Republike Hrvatske (Narodne novine, br. 56/1990, 135/1997, 08/1998, 113/2000, 124/2000, 28/2001, 41/2001, 55/2001, 76/2010, 85/2010, 05/2014).

14 Odlukom Ustavnog suda RH br. U-II-1118/2013 od 22. svibnja 2013. (Narodne novine, br. 63/2013) ukinuta je Odluka o uvođenju, praćenju i vrednovanju provedbe Kurikuluma zdravstvenog odgoja u osnovnim i srednjim školama (Narodne novine, br. 26/2013), a Odlukom Ustavnog suda RH br. U-II-1304/2013. od 16. srpnja 2013. (Narodne novine, br. 99/2013) ukinut je Pravilnik o uvjetima za izbor u znanstvena zvanja (Narodne novine, br. 34/2013). Vidi Musa, A.; Vidačak, I.; Volmut, I.; Pernar, S., Priručnik za provedbu savjetovanja s javnošću za jedinice lokalne i područne (regionalne) samouprave, Povjerenik za informiranje, Zagreb, 2016., str. 14 - 15.

15 Zakon o pravu na pristup informacijama (Narodne novine, br. 25/2013, 85/2015). Povjerenik za informiranje objavio je 2016. Smjernice za provedbu čl. 11. ZPPI-ja o provedbi savjetovanja s javnošću, s pojašnjenjima i preporukama za postupanje $u$ vezi s pojedinim stavcima odredbe o savjetovanjima.

16 Kodeks savjetovanja sa zainteresiranom javnošću u postupcima donošenja zakona, drugih propisa i akata (Narodne novine, br. 140/2009).

17 Kada je riječ o sustavnim zakonima u području javne uprave, održavanje javnih rasprava pri izradi nacrta propisa bilo je predviđeno i Zakonom o sustavu državne uprave (ZSDU) iz 1993. te je zadržano sve do donošenja novoga Zakona 2019. godine. Čl. 79. st. 2. ZSDU-a (Narodne novine, br. 150/2011, 12/2013, 93/2016, 104/2016) predviđao je mogućnost čelnika upravne organizacije da odluči objaviti nacrte propisa za koje je javnost posebno zainteresirana te da se pozovu zainteresirani dionici na podnošenje komentara. I Zakon o ustanovama (Narodne novine, br. 76/1993, 29/1997, 47/1999, 35/2008, 127/2019) propisuje obavještavanje javnosti 
o procjeni učinaka propisa i pripadajuća Uredba ${ }^{18}$ reguliraju savjetovanje kao sastavni dio postupka procjene učinaka propisa. Savjetovanja su predmet i posebnih zakona (npr. Zakon o zaštiti okoliša ${ }^{19}$, Zakon o prostornom uređenju ${ }^{20}$, Zakon o održivom gospodarenju otpadom ${ }^{21}$ ), kojima se predviđa način provedbe savjetovanja u sektorskim područjima (posebni režimi savjetovanja). Pritom je nužno osigurati ispunjavanje svih uvjeta propisanih ZPPI-jem jer u suprotnom obveza savjetovanja, iako ispunjena prema posebnom propisu, ostaje neispunjena prema sustavnom Zakonu. ${ }^{22}$ Poslovnik Vlade $\mathrm{RH}^{23}$ i Poslovnik Hrvatskog sabo$\mathrm{ra}^{24}$ sadržavaju odredbe koje predviđaju savjetovanja s javnošću kao obvezatan korak zakonodavnog procesa. Izvješća o provedenom savjetovanju tako čine obvezni dio dokumentacije koja se s nacrtom prijedloga zakona, drugog propisa ili akta upućuje u Vladinu odnosno saborsku proceduru.

ZPPI u čl. 11. propisuje obvezu tijelima javne vlasti da provode savjetovanja s javnošću. St. 1. specificira obveznike provedbe savjetovanja te akte obuhvaćene tom obvezom. Riječ je o tijelima državne uprave, drugim državnim tijelima, jedinicama lokalne i područne (regionalne) samouprave te pravnim osobama s javnim ovlastima. Akti o čijem donošenju je riječ jesu zakoni i podzakonski propisi, kao i opći akti te strateški i planski dokumenti kada se njima utječe na interese fizičkih i pravnih osoba. St. 2. istog članka određuje način (konkretnu metodu) provedbe savjetovanja - internetsko (online) savjetovanje. Pritom tijela

od strane javne ustanove kada "održava znanstvena, stručna i druga savjetovanja i skupove o pitanjima za koje je javnost zainteresirana" (čl. 63.). Više u: Musa, A., Pravni i institucionalni aspekti prava na pristup informacijama i transparentnosti $u$ Republici Hrvatskoj, u: Arbutina, H.; Rogić Lugarić, T. (ur.), Spomenica prof. dr. sc. Juri Šimoviću, Pravni fakultet Sveučilišta u Zagrebu, Zagreb, 2017., str. 461 - 462.

18 Zakon o procjeni učinaka propisa (Narodne novine, br. 44/2017) i Uredba o provedbi postupka procjene učinaka propisa (Narodne novine, br. 52/2017).

19 Zakon o zaštiti okoliša (Narodne novine, br. 80/2013, 153/2013, 78/2015, 12/2018, 118/2018).

20 Zakon o prostornom uređenju (Narodne novine, br. 153/2013, 65/2017, 114/2018, 39/2019).

${ }^{21}$ Zakon o održivom gospodarenju otpadom (Narodne novine, br. 94/2013, 73/2017, 14/2019).

22 Smjernice za primjenu članka 11. Zakona o pravu na pristup informacijama (Narodne novine, br. 25/2013 i 85/2015) - savjetovanja s javnošću; Musa et al., op. cit. u bilj. 14, str. $15-16$.

23 Poslovnik Vlade RH (Narodne novine, br. 154/2011, 121/2012, 7/2013, 61/2015, 99/2016, 57/2017).

24 Poslovnik Hrvatskog sabora (Narodne novine, br. 81/2013, 113/2016, 69/2017, 29/2018). 
državne uprave savjetovanje provode preko središnjeg državnog internetskog portala za savjetovanja s javnošću ${ }^{25}$, dok druga državna tijela, jedinice lokalne i područne (regionalne) samouprave te pravne osobe s javnim ovlastima mogu izabrati između središnjeg portala ili vlastite odnosno neke druge internetske stranice ili portala. Zakon, dakle, nalaže provedbu elektroničkog savjetovanja kao obveznog za sva tijela javne vlasti, ali dopušta mogućnost i drugih, fakultativnih metoda savjetovanja (fizičke javne rasprave, fokus grupe i sl.).

Obveznici provedbe savjetovanja dužni su objaviti nacrt propisa, općeg akta odnosno drugog dokumenta s obrazloženjem razloga i ciljeva koji se žele postići njihovim donošenjem te s pozivom javnosti da dostavi svoje prijedloge i mišljenja (st. 2.). Rok za savjetovanje određen je u trajanju u pravilu 30 dana, uz iznimku koju predstavljaju slučajevi u kojima se savjetovanje provodi prema Zakonu o procjeni učinka propisa (st. 3.). Prema smjernicama Povjerenika za informiranje, nadzornog tijela u odnosu na provedbu savjetovanja, iznimku predstavljaju i opravdane izvanredne okolnosti poput potrebe da se ispune uvjeti za korištenje fondova EU-a, obveze u skladu s međunarodnim ugovorima, slučajevi elementarne nepogode i sl. Osim toga, iznimka je dopuštena u slučajevima izmjena i dopuna akata kojima se oni tehnički usklađuju s aktima više razine. No, ako se uz tehničke pristupi i sadržajnim izmjenama, savjetovanje se mora provesti u roku od 30 dana. ${ }^{26}$ Nakon provedenog savjetovanja tijela javne vlasti obvezna su objaviti izvješće o provedenom savjetovanju koje treba sadržavati sve zaprimljene komentare javnosti te obrazloženja tijela za njihovo neprihvaćanje, a tijela državne uprave dužna su nacrtu propisa koji upućuju u Vladinu proceduru priložiti izvješće o provedenom savjetovanju (st. 4.). Uz navedeno, tijela javne vlasti dužna su objaviti na svojim internetskim stranicama godišnji plan savjetovanja o nacrtima zakona i drugih propisa, koji sadržava naziv propisa, općeg akta ili dokumenta, očekivano vrijeme njegova donošenja, okvirno vrijeme provedbe internetskog savjetovanja te druge predviđene načine na koje se namjerava provesti savjetovanje (st. 6.).

Donošenje Kodeksa 2009. godine predstavljalo je početnu fazu u normativnoj regulaciji savjetovanja s javnošću u RH, dok je ključni iskorak predstavljalo donošenje novoga ZPPI-ja 2013. godine. Odredbe Kodeksa nemaju pravno obvezujuću snagu te se primarno odnose na tijela državne uprave i urede Vlade, dok za tijela jedinica lokalne i područne (regionalne) samouprave te pravne osobe s javnim ovlastima konstatira "odgovarajuću primjenu” (čl. 9.). Uz propisivanje standarda

25 https://esavjetovanja.gov.hr/ECon/Dashboard.

26 Smjernice za primjenu članka 11. Zakona o pravu na pristup informacijama (Narodne novine, br. 25/2013 i 85/2015) - savjetovanja s javnošću; Musa et al., op. cit. u bilj. 14, str. 29 . 
o jasnoći, trajanju savjetovanja, pravodobnom informiranju javnosti o donošenju zakona, drugog propisa odnosno akta te o učincima provedenog savjetovanja, Kodeks nalaže usklađenost u pogledu provedbe savjetovanja u svim tijelima državne uprave, za što predviđa imenovanje koordinatora za savjetovanje (čl. 5.). Ured za udruge Vlade RH (UUVRH) donio je 2010. Smjernice za primjenu Kodeksa. ${ }^{27}$ Do srpnja 2019. godine, kada poslove vezane uz savjetovanja s javnošću preuzima Ured za zakonodavstvo Vlade RH. UUVRH bio je nadležan za nadzor nad provedbom Kodeksa podnošenjem godišnjih izvješća te je obavljao administrativno-koordinativne poslove oko portala eSavjetovanja.

ZPPI-jem je 2013. predviđena zakonska obveza provedbe savjetovanja za sva tijela javne vlasti, ali i institucionalni mehanizam za nadzor nad ispunjavanjem te zakonske obveze - Povjerenik za informiranje (PI). ZPPI propisuje znatno duži rok za provođenje savjetovanja (30 dana u odnosu na 15 dana prema Kodeksu) te predviđa provođenje inspekcijskog nadzora od strane povjerenika za informiranje kojim se, među ostalim, utvrđuje provode li tijela javne vlasti savjetovanja s javnošću u skladu s čl. 11. Zakonom je predviđeno i sankcioniranje tijela javne vlasti koja ne postupe u roku prema odluci Povjerenika (čl. 61. st. 1.), odnosno koja ne postupe prema nalogu Povjerenika (čl. 62.). Odredbe ZPPI-ja, kao pravno superiornijeg akta po načelima lex superior derogat legi inferiori i lex posterior derogat legi priori imaju prednost pred odredbama Kodeksa te su odredbe Kodeksa za tijela javne vlasti obvezujuće samo u dijelu u kojem se ne kose s odredbama Zakona. ${ }^{28}$

\subsection{Usklađenost hrvatskoga normativnog okvira s međunarodnim standardima savjetovanja s javnošću}

Načela i standardi vezani uz provedbu savjetovanja s javnošću predmet su akata i dokumenata nekolicine europskih i međunarodnih organizacija, prije svega EU-a, Vijeća Europe (VE) i Ujedinjenih naroda (UN). Oni pripadaju i u sferu tvrdog i u sferu mekog prava. Pritom se akti obvezujuće prirode pretežno odnose na savjetovanja s javnošću u posebnim sektorskim područjima, poput politike zaštite okoliša koju obilježava duža tradicija uključivanja javnosti. Akti koji se odnose na opći režim savjetovanja neobvezujuće su prirode i uključuju preporuke, kodekse, smjernice i sl.

27 https://savjetovanja.gov.hr/UserDocsImages/dokumenti/kopija/Savjetovanja/Smjernice_PDF.pdf.

28 Musa et al., op. cit. u bilj. 14, str. 12. 
Na razini EU-a načelne odredbe vezane uz participaciju javnosti u oblikovanju javnih politika i propisa sadržane su u temeljnim pravnim aktima EU-a - Ugovoru o EU-u i Ugovoru o funkcioniranju EU-a, dok Bijela knjiga o europskom upravljanju iz 2001. proklamira načela otvorenosti i participacije. Opća regulacija savjetovanja ne postoji na razini obvezujućih akata; države članice obvezne su pridržavati se pravila konzultiranja javnosti u pitanjima koja se odnose na posebna područja javnih politika ${ }^{29}$, dok sustavne odredbe vezane uz savjetovanja postoje na razini preporuka. Standardi za savjetovanja s javnošću sadržani su u Komisijinim Općim načelima i minimalnim standardima za konzultiranje zainteresirane javnosti iz 2002. te Mandelkernovom izvješću o boljoj regulaciji ${ }^{30}$ iz 2000. Oba dokumenta sadržavaju slične preporuke vezane uz jasnoću i transparentnost procesa savjetovanja, rano uključivanje zainteresirane javnosti, dopunjavanje tradicionalnih instrumenata participacije javnosti s internetskim, dostupnost komentara široj javnosti, dostatno trajanje savjetovanja te povratne informacije sudionicima.

Dokumenti VE-a ponajprije su usmjereni na postavljanje šireg okvira i temeljnih načela za demokratično upravljanje i vladavinu prava, posebno na lokalnoj razini vlasti. ${ }^{31}$ Participacija kao fundamentalno načelo i pravo sadržana je u Europskoj povelji o lokalnoj samoupravi iz 1985. te u njezinu Protokolu o pravu na sudjelovanje u poslovima lokalne vlasti iz 2009., u kojima se procedure za konzultiranje javnosti navode kao jedan od mehanizama jačanja lokalne participacije. Standardi koji se implicitno odnose na savjetovanja s javnošću kao jedan od instrumenata participacije građana sadržani su, primjerice, u Preporuci Odbora ministara Rec(2001)19 o participaciji u lokalnom javnom životu iz 2018. ${ }^{32}$, Preporuci Odbora ministara o e-demokraciji CM/REC(2009)I iz 2009., Kodeksu sudjelovanja građana u odlučivanju iz 2009., Smjernicama

29 Vidi, primjerice, Ofak, L., Sudjelovanje javnosti u odlučivanju u pitanjima okoliša, Hrvatska javna uprava: časopis za teoriju i praksu javne uprave, vol. 9, br. 2, 2009., str. $443-470$.

30 Preporuke radne skupine na čelu s Dieudonnéom Mandelkernom odnosile su se na simplifikaciju, procjenu učinaka novih propisa, razmatranje policy alternativa, transparentnost i razumljivost regulacije, s ciljem povećanja kompetitivnosti europskog gospodarstva, rasta standarda europskih građana i veće legitimnosti institucija.

31 Spektar dokumenata koji se odnose ne neki oblik participacije ili uključivanja građana u procese javnog odlučivanja vrlo je širok. Više u: Musa, A.; Dobrić Jambrović, D., Participacija na lokalnoj razini kao standard Vijeća Europe: uloga Europske povelje o lokalnoj samoupravi i Protokola o pravu na sudjelovanje u poslovima lokalnih vlasti, u: Koprić, I. (ur.), Europeizacija hrvatske lokalne samouprave: Dva desetljeća primjene Europske povelje o lokalnoj samoupravi, Institut za javnu upravu, Zagreb, 2018., str. 292 - 312.

32 Preporuka je donesena 2001. te revidirana u ožujku 2018. 
za sudjelovanje javnosti u političkom odlučivanju iz 2017. i dr. Standardi na koje upućuju navedeni dokumenti uključuju jasnoću savjetovanja i informiranje javnosti, oslanjanje na IKT i širok spektar instrumenata participacije građana, upućivanje povratne informacije javnosti o učincima sudjelovanja te aktivni angažman predstavnika javnih tijela.

Participacija javnosti u donošenju propisa i politika sadržana je, kao opće načelo ili kroz razradu standarda, u aktima i drugim dokumentima UN-a koji se odnose na pitanja okoliša, uključujući veći broj potpodručja ove posebne javne politike te na prostorno planiranje. Aarhuška konvencija (Konvencija o pristupu informacijama, sudjelovanju javnosti i pristupu pravosuđu u pitanjima okoliša) u tom je pogledu najpoznatiji, ali i najvažniji akt jer pobliže određuje nekolicinu standarda ${ }^{33}$ za provedbu participacije javnosti u izradi propisa i politika ${ }^{34}$, dok se u drugim aktima i dokumentima participacija uglavnom zagovara načelno.

Među ostalim međunarodnim organizacijama valja spomenuti OECD, koji promovira participaciju javnosti putem doktrine dobrog upravljanja. Među temeljnim načelima za uspješno participiranje građana, koja se navode u priručniku iz 2001. Građani kao partneri: informiranje, konzultiranje i participiranje građana u oblikovanju javnih politika, jesu jasnoća ciljeva, dostatno trajanje procesa participacije, rano uključivanje javnosti u proces, predanost političkih dužnosnika i upravnih službenika i dr. ${ }^{35}$

33 Na participaciju javnosti odnose se članci 6. - 8. Konvencije. Standardi se odnose na pravodobno informiranje javnosti o mogućnosti participiranja pri donošenju planskih i programskih akata u području okoliša, osiguravanje dostatnih vremenskih rokova za participaciju te što je moguće veće mjere uvažavanja rezultata. Standardi Aarhuške konvencije preneseni su i u europski pravni sustav. Godine 2003. donesena je Direktiva 2003/4/EZ Europskog parlamenta i Vijeća, koja predviđa pravo na pristup informacijama u pitanjima okoliša, te Direktiva 2003/35/EZ Europskog parlamenta i Vijeća o osiguravanju sudjelovanja javnosti u izradi određenih planova i programa koji se odnose na okoliš, radi olakšavanja primjene Konvencije. EU je Konvenciju ratificirao 17. veljače 2005. Odlukom Vijeća 2005/370/EZ o zaključivanju, u ime Europske zajednice, Konvencije o pristupu informacijama, sudjelovanju javnosti u odlučivanju i pristupu pravosuđu u pitanjima okoliša. Sljedeće je godine donesena Uredba br. 1367/2006 Europskog parlamenta i Vijeća o primjeni odredaba Aarhuške konvencije o pristupu informacijama, sudjelovanju javnosti u odlučivanju i pristupu pravosuđu u pitanjima okoliša na institucije i tijela Zajednice.

34 Vidi Ofak, L., Application of the Aarhus Convention in Southeast Europe, u: Rodin, S.; Perišin, T. (ur.), Judicial Application of International Law in Southeast Europe, Springer, Heidelberg, New York, Dordrecht, London, 2015., str. 43 - 62.

OECD, op. cit. u bilj. 8, str. 16. 
Uz šira načela transparentnosti, otvorenosti, responzivnosti i povjerenja, moguće je izdvojiti sedam temeljnih međunarodnih standarda za provedbu savjetovanja, od kojih su svi prisutni u hrvatskome normativnom okviru: (i) pravodobno informiranje (obavještavanje) javnosti o savjetovanju; (ii) jasnoća procesa savjetovanja; (iii) pravodobno/rano uključivanje javnosti; (iv) dostatno trajanje savjetovanja; (v) oslanjanje na višestruke metode i na suvremeni IKT; (vi) predanost i edukacija upravnih službenika i dužnosnika za provedbu savjetovanja; (vii) davanje povratne informacije sudionicima o rezultatima savjetovanja (vidi Tablicu 1). Osim toga, navedeni, ali i dodatni standardi (npr. identificiranje zainteresirane javnosti i uključivanje što šireg kruga zainteresirane javnosti, usmjerenost na što je moguće višu razinu uvažavanja komentara sudionika) sadržani su u Smjernicama Povjerenika za informiranje za primjenu članka 11. ZPPI-ja te Smjernicama Ureda za udruge Vlade RH za provedbu Kodeksa. Pojedini se standardi pronalaze i u posebnim zakonima (obavještavanje javnosti, trajanje savjetovanja i davanje povratne informacije o rezultatima savjetovanja), no ovdje se zbog fokusiranosti i preglednosti ograničavamo na opći režim savjetovanja na međunarodnoj i nacionalnoj razini. Zaključno se može ustvrditi kako usporedba nacionalnih odredbi s međunarodnim standardima za provedbu savjetovanja upućuje na međusobnu usklađenost, tj. relevantni standardi za provedbu savjetovanja definirani od strane europskih i međunarodnih institucija usvojeni su u domaćem zakonodavstvu u opsegu koji se može smatrati širim od minimalnog. 
Tablica 1. Standardi za provedbu savjetovanja s javnošću u međunarodnim dokumentima i hrvatskom zakonodavstvu

\begin{tabular}{|c|c|c|c|c|}
\hline STANDARD & $\begin{array}{c}\text { MEĐU- } \\
\text { NARODNI AKT } \\
\text { / DOKUMENT }\end{array}$ & $\begin{array}{c}\text { OPIS } \\
\text { ODREDBE }\end{array}$ & $\begin{array}{l}\text { NACIO- } \\
\text { NALNI } \\
\text { PRAVNI } \\
\text { PROPIS } \\
\end{array}$ & $\begin{array}{c}\text { OPIS } \\
\text { ODREDBE }\end{array}$ \\
\hline $\begin{array}{l}\text { pravodobno } \\
\text { informiranje } \\
\text { javnosti o } \\
\text { savjetovanju }\end{array}$ & $\begin{array}{l}\text { Opća načela } \\
\text { i minimalni } \\
\text { standardi za } \\
\text { konzultiranje } \\
\text { zainteresirane } \\
\text { javnosti (EK) } \\
\text { Mandelkernovo } \\
\text { izvješće o boljoj } \\
\text { regulaciji (EU) }\end{array}$ & $\begin{array}{l}\text { Potrebno je osigurati } \\
\text { adekvatno informiranje } \\
\text { i podizanje svijesti } \\
\text { javnosti te sredstva } \\
\text { komuniciranja } \\
\text { prilagoditi ciljanim } \\
\text { skupinama. } \\
\text { Javnost je potrebno } \\
\text { što ranije, na širokoj } \\
\text { bazi, informirati o } \\
\text { postupku savjetovanja; } \\
\text { svi na koje se neki akt } \\
\text { odnosi, trebaju imati } \\
\text { mogućnost uključivanja } \\
\text { u savjetovanje. } \\
\text { Potrebno je na vrijeme } \\
\text { obavijestiti javnost o } \\
\text { postupcima savjetovanja } \\
\text { koji će se održati. }\end{array}$ & $\begin{array}{l}\text { Kodeks, } \\
\text { čl. V. t. I. }\end{array}$ & $\begin{array}{l}\text { Tijela javne vlasti moraju na } \\
\text { svojoj internetskoj stranici } \\
\text { objaviti plan savjetovanja } \\
\text { s javnošću za kalendarsku } \\
\text { godinu te obavještavati } \\
\text { javnost o njegovim } \\
\text { promjenama. } \\
\text { Tijela javne vlasti moraju } \\
\text { objaviti nacrt akta o kojem se } \\
\text { provodi savjetovanje, zajedno } \\
\text { s pozivom javnosti da dostavi } \\
\text { svoje prijedloge i mišljenja. } \\
\text { Javnost je potrebno } \\
\text { pravodobno informirati o } \\
\text { planu donošenja zakona, } \\
\text { drugih propisa i akata } \\
\text { objavom popisa akata koji } \\
\text { se predlažu donijeti u } \\
\text { kalendarskoj godini. }\end{array}$ \\
\hline $\begin{array}{l}\text { jasnoća } \\
\text { procesa } \\
\text { savjetovanja }\end{array}$ & $\begin{array}{l}\text { Mandelkernovo } \\
\text { izvješće o boljoj } \\
\text { regulaciji (EU) } \\
\\
\text { Opća načela } \\
\text { i minimalni } \\
\text { standardi za } \\
\text { konzultiranje } \\
\text { zainteresirane } \\
\text { javnosti (EK) } \\
\text { Smjernice za } \\
\text { sudjelovanje } \\
\text { javnosti u } \\
\text { političkom } \\
\text { odlučivanju (VE) } \\
\text { Kodeks } \\
\text { sudjelovanja } \\
\text { građana u } \\
\text { odlučivanju (VE) } \\
\\
\text { Smjernice Građani } \\
\text { kao partneri: } \\
\text { informiranje, } \\
\text { konzultiranje i } \\
\text { participiranje } \\
\text { građana u } \\
\text { oblikovanju javnih } \\
\text { politika (OECD) }\end{array}$ & $\begin{array}{l}\text { Tijekom savjetovanja } \\
\text { potrebno je osigurati } \\
\text { dodatne informacije i } \\
\text { obrazloženja za javnost. } \\
\text { Potrebno je osigurati } \\
\text { jasan sadržaj procesa } \\
\text { savjetovanja, što } \\
\text { uključuje cilj, opseg i } \\
\text { kontekst savjetovanja. } \\
\\
\text { Javnosti trebaju biti } \\
\text { dostupne jasne i } \\
\text { pravodobne informacije } \\
\text { vezane uz proces } \\
\text { participacije. } \\
\text { Procedure za } \\
\text { participaciju trebaju } \\
\text { biti jasne, otvorene i } \\
\text { dostupne; jednostavan } \\
\text { i slobodan pristup svim } \\
\text { aktima i dokumentima. } \\
\text { Svim sudionicima treba- } \\
\text { ju biti jasni ciljevi parti- } \\
\text { cipiranja te uloge i odgo- } \\
\text { vornost svih uključenih } \\
\text { aktera; informacije koje } \\
\text { se pružaju građanima } \\
\text { moraju biti objektivne i } \\
\text { dostupne. }\end{array}$ & $\begin{array}{l}\text { Smjernice } \\
\text { za } \\
\text { primjenu } \\
\text { Kodeksa }\end{array}$ & $\begin{array}{l}\text { Tijela javne vlasti moraju } \\
\text { prilikom objave nacrta akta o } \\
\text { kojem se provodi savjetovanje } \\
\text { objaviti i obrazloženje razloga } \\
\text { i ciljeva koji se žele postići } \\
\text { njegovim donošenjem. } \\
\text { TDU i uredi Vlade trebaju } \\
\text { dati jasno pojašnjenje pitanja } \\
\text { o kojima se traži povratna } \\
\text { informacija zainteresirane } \\
\text { javnosti, navesti mjere koje } \\
\text { se u postupku savjetovanja } \\
\text { koriste i razloge za donošenje } \\
\text { zakona. } \\
\text { Nacrti zakona, drugih } \\
\text { propisa i akata trebaju se } \\
\text { objaviti na internetskim } \\
\text { stranicama ili na drugi način, } \\
\text { zajedno s obavijesti i pozivom } \\
\text { na savjetovanje, koji trebaju } \\
\text { biti jasni i sažeti. } \\
\text { Poziv javnosti na savjetovanje } \\
\text { treba biti popraćen jasnim, } \\
\text { detaljnim i razumljivim } \\
\text { obrazloženjem razloga i } \\
\text { ciljeva donošenja akta; } \\
\text { to je moguće učiniti na } \\
\text { standardiziranom obrascu } \\
\text { koji se prilaže Smjernicama. }\end{array}$ \\
\hline
\end{tabular}




\begin{tabular}{|c|c|c|c|c|}
\hline STANDARD & $\begin{array}{c}\text { MEĐU- } \\
\text { NARODNI AKT } \\
\text { / DOKUMENT }\end{array}$ & $\begin{array}{c}\text { OPIS } \\
\text { ODREDBE }\end{array}$ & $\begin{array}{l}\text { NACIO- } \\
\text { NALNI } \\
\text { PRAVNI } \\
\text { PROPIS }\end{array}$ & $\begin{array}{c}\text { OPIS } \\
\text { ODREDBE }\end{array}$ \\
\hline $\begin{array}{l}\text { pravodobno/ } \\
\text { rano } \\
\text { uključivanje } \\
\text { javnosti }\end{array}$ & $\begin{array}{l}\text { Opća načela } \\
\text { i minimalni } \\
\text { standardi za } \\
\text { konzultiranje } \\
\text { zainteresirane } \\
\text { javnosti (EK) } \\
\text { Mandelkernovo } \\
\text { izvješće o boljoj } \\
\text { regulaciji (EU) } \\
\\
\\
\text { Smjernice Građani } \\
\text { kao partneri: } \\
\text { informiranje, } \\
\text { konzultiranje i } \\
\text { participiranje } \\
\text { građana u } \\
\text { oblikovanju javnih } \\
\text { politika (OECD) }\end{array}$ & $\begin{array}{l}\text { Proces savjetovanja } \\
\text { trebao bi se odvijati } \\
\text { u što ranijoj fazi } \\
\text { donošenja akta. } \\
\\
\text { Savjetovanja se trebaju } \\
\text { odvijati dovoljno rano } \\
\text { tijekom regulativnog } \\
\text { procesa kako bi se } \\
\text { osigurala mogućnost } \\
\text { utjecaja javnosti na } \\
\text { ishode procesa. } \\
\text { Važno je rano } \\
\text { uključivanje javnosti u } \\
\text { proces participiranja. }\end{array}$ & $\begin{array}{l}\text { Smjernice } \\
\text { za } \\
\text { primjenu } \\
\text { Kodeksa }\end{array}$ & $\begin{array}{l}\text { Savjetovanje je potrebno } \\
\text { provesti u ranijoj fazi } \\
\text { izrade zakona, propisa i } \\
\text { drugih akata, kada postoji } \\
\text { mogućnost utjecaja na } \\
\text { promjene i doradu nacrta } \\
\text { propisa. } \\
\text { Predstavnici zainteresirane } \\
\text { javnosti trebali bi biti } \\
\text { identificirani dovoljno rano } \\
\text { kako bi se sam postupak } \\
\text { istima mogao prilagoditi } \\
\text { i kako bi javnost stigla } \\
\text { procijeniti relevantnost } \\
\text { predmeta savjetovanja. }\end{array}$ \\
\hline $\begin{array}{l}\text { dostatno } \\
\text { trajanje } \\
\text { savjetovanja }\end{array}$ & \begin{tabular}{|l} 
Mandelkernovo \\
izvješće \\
o boljoj regulaciji \\
(EU) \\
Opća načela \\
i minimalni \\
standardi za \\
konzultiranje \\
zainteresirane \\
javnosti (EK) \\
Smjernice Građani \\
kao partneri: \\
informiranje, \\
konzultiranje i \\
participiranje \\
građana u \\
oblikovanju javnih \\
politika (OECD) \\
\end{tabular} & $\begin{array}{l}\text { Osigurati dovoljan } \\
\text { rok za konzultiranje } \\
\text { javnosti, u skladu s } \\
\text { danim okolnostima. } \\
\text { Trajanje savjetovanja } \\
\text { koja provodi Komisija } \\
\text { minimalno } 8 \text { tjedana. } \\
\\
\\
\text { Proces participacije } \\
\text { treba se odvijati } \\
\text { u dostatnom } \\
\text { vremenskom okviru. }\end{array}$ & $\begin{array}{l}\text { ZPPI, čl. } \\
\text { 1l. st. } 3 . \\
\\
\text { Kodeks, } \\
\text { čl. V. t. } 3 . \\
\text { Smjernice } \\
\text { za } \\
\text { primjenu } \\
\text { Kodeksa }\end{array}$ & $\begin{array}{l}\text { Tijela javne vlasti trebaju } \\
\text { provesti savjetovanje } \\
\text { u trajanju u pravilu } 30 \text { dana. } \\
\text { Savjetovanje ne bi trebalo } \\
\text { trajati kraće od } 15 \text { dana. } \\
\text { Kada se savjetovanje } \\
\text { provodi u razdobljima manje } \\
\text { vjerojatnosti da će širi krug } \\
\text { zainteresirane javnosti } \\
\text { sudjelovati (ljetni praznici } \\
\text { ili božićni blagdani), kao i u } \\
\text { slučajevima kad je određena } \\
\text { politika osobito kompleksna, } \\
\text { poželjno je produžiti trajanje } \\
\text { savjetovanja. }\end{array}$ \\
\hline
\end{tabular}




\begin{tabular}{|c|c|c|c|c|}
\hline STANDARD & $\begin{array}{c}\text { MEĐU- } \\
\text { NARODNI AKT } \\
\text { / DOKUMENT }\end{array}$ & $\begin{array}{c}\text { OPIS } \\
\text { ODREDBE }\end{array}$ & \begin{tabular}{|l} 
NACIO- \\
NALNI \\
PRAVNI \\
PROPIS
\end{tabular} & $\begin{array}{c}\text { OPIS } \\
\text { ODREDBE }\end{array}$ \\
\hline $\begin{array}{l}\text { višestruki } \\
\text { instrumenti / } \\
\text { oslanjanje na } \\
\text { IKT }\end{array}$ & $\begin{array}{l}\text { Opća načela } \\
\text { i minimalni } \\
\text { standardi za } \\
\text { konzultiranje } \\
\text { zainteresirane } \\
\text { javnosti (EK) } \\
\text { Protokol uz } \\
\text { Europsku povelju } \\
\text { o lokalnoj } \\
\text { samoupravi, čl. } 2 . \\
\text { (VE) } \\
\\
\text { Preporuka } \\
\text { Odbora ministara } \\
\text { o participaciji } \\
\text { u lokalnom } \\
\text { javnom životu } \\
\text { Rec(2001)19 (VE) } \\
\text { Preporuka Odbora } \\
\text { ministara o } \\
\text { e-demokraciji Cm/ } \\
\text { Rec(2009)1 (VE) }\end{array}$ & $\begin{array}{l}\text { Poželjno je koristiti } \\
\text { online instrumente } \\
\text { konzultiranja javnosti } \\
\text { koji omogućuju } \\
\text { participaciju širokog } \\
\text { kruga sudionika; } \\
\text { mogućnost korištenja } \\
\text { palete konzultativnih } \\
\text { instrumenata, } \\
\text { ovisno o tome što } \\
\text { je najprikladnije s } \\
\text { obzirom na akt i } \\
\text { kontekst u kojem se } \\
\text { donosi; kombinacija } \\
\text { tradicionalnih i novih } \\
\text { instrumenata. } \\
\text { Oslanjanje na } \\
\text { kombinaciju } \\
\text { tradicionalnih offline } \\
\text { i online instrumenata } \\
\text { konzultiranja javnosti. } \\
\\
\text { Potrebno je jačati } \\
\text { korištenje IKT-a u } \\
\text { ostvarivanju prava } \\
\text { građana da participiraju. }\end{array}$ & $\begin{array}{l}\text { Smjernice } \\
\text { za } \\
\text { primjenu } \\
\text { članka } 11 . \\
\text { ZPPI-ja }\end{array}$ & $\begin{array}{l}\text { Tijela državne uprave } \\
\text { provode savjetovanja preko } \\
\text { središnjeg internetskog } \\
\text { portala, a druga državna } \\
\text { tijela, jedinice lokalne i } \\
\text { regionalne samouprave } \\
\text { i pravne osobe s javnim } \\
\text { ovlastima preko internetske } \\
\text { stranice ili središnjeg portala } \\
\text { Savjetovanje je moguće } \\
\text { provesti, osim kao } \\
\text { internetsko, u obliku javnih } \\
\text { okupljanja ili skupova, } \\
\text { distribucijom nacrta propisa } \\
\text { zainteresiranoj javnosti } \\
\text { elektroničkom poštom, } \\
\text { sudjelovanjem u radnim } \\
\text { skupinama i dr. } \\
\text { Postupak savjetovanja može } \\
\text { obuhvatiti i uključivanje } \\
\text { stručnjaka iz reda } \\
\text { predstavnika zainteresirane } \\
\text { javnosti imenovanjem u } \\
\text { stručne radne skupine } \\
\text { te organiziranje javnih } \\
\text { savjetovanja o financijskim, } \\
\text { gospodarskim, socijalnim, } \\
\text { okolišnim i ljudskopravnim } \\
\text { učincima donošenja i } \\
\text { provedbe određenih zakona, } \\
\text { drugih propisa i akata. } \\
\text { Provedba savjetovanja } \\
\text { s javnošću, osim u } \\
\text { online obliku, može biti } \\
\text { upotpunjena i drugim } \\
\text { oblicima, tj. instrumentima } \\
\text { participacije - offline javne } \\
\text { rasprave, radne grupe za } \\
\text { izradu nacrta propisa i sl. } \\
\text { Primjeri različitih metoda } \\
\text { za savjetovanje s javnošću } \\
\text { uključuju ankete, fokus } \\
\text { grupe, radionice itd. }\end{array}$ \\
\hline
\end{tabular}




\begin{tabular}{|c|c|c|c|c|}
\hline STANDARD & $\begin{array}{c}\text { MEĐU- } \\
\text { NARODNI AKT } \\
\text { / DOKUMENT }\end{array}$ & $\begin{array}{c}\text { OPIS } \\
\text { ODREDBE }\end{array}$ & $\begin{array}{l}\text { NACIO- } \\
\text { NALNI } \\
\text { PRAVNI } \\
\text { PROPIS }\end{array}$ & $\begin{array}{c}\text { OPIS } \\
\text { ODREDBE }\end{array}$ \\
\hline $\begin{array}{l}\text { predanost } \\
\text { i edukacija } \\
\text { upravnih } \\
\text { službenika i } \\
\text { dužnosnika }\end{array}$ & $\begin{array}{l}\text { Smjernice Građani } \\
\text { kao partneri: } \\
\text { informiranje, } \\
\text { konzultiranje i } \\
\text { participiranje } \\
\text { građana u } \\
\text { oblikovanju javnih } \\
\text { politika (OECD) } \\
\text { Kodeks } \\
\text { sudjelovanja } \\
\text { građana u } \\
\text { odlučivanju (VE) }\end{array}$ & $\begin{array}{l}\text { Uspješnost } \\
\text { participiranja građana } \\
\text { ovisi i o predanosti } \\
\text { političkih dužnosnika i } \\
\text { upravnih službenika. } \\
\\
\\
\text { Predstavnici javnih } \\
\text { tijela trebaju se aktivno } \\
\text { angažirati tijekom } \\
\text { procesa savjetovanja. }\end{array}$ & $\begin{array}{l}\text { ZPPI, čl. } \\
\text { 35. st. } 3 . \\
\text { t. } 6 .\end{array}$ & $\begin{array}{l}\text { Povjerenik u okviru svojih } \\
\text { Zakonom definiranih } \\
\text { poslova predlaže mjere za } \\
\text { stručno osposobljavanje i } \\
\text { usavršavanje službenika za } \\
\text { informiranje radi njihova } \\
\text { upoznavanja sa zakonskim } \\
\text { obvezama. }\end{array}$ \\
\hline \begin{tabular}{|l} 
povratna \\
informacija o \\
rezultatima \\
savjetovanja
\end{tabular} & $\begin{array}{l}\text { Opća načela } \\
\text { i minimalni } \\
\text { standardi za } \\
\text { konzultiranje } \\
\text { zainteresirane } \\
\text { javnosti (EK) } \\
\text { Mandelkernovo } \\
\text { izvješće o boljoj } \\
\text { regulaciji (EU) } \\
\\
\text { Kodeks } \\
\text { sudjelovanja } \\
\text { građana u } \\
\text { odlučivanju (VE) } \\
\text { Preporuka } \\
\text { Odbora ministara } \\
\text { Rec(2001)19 o } \\
\text { participaciji u } \\
\text { lokalnom javnom } \\
\text { životu (VE) }\end{array}$ & $\begin{array}{l}\text { Upućivanje } \\
\text { individualnih } \\
\text { informacija ili } \\
\text { zajedničke povratne } \\
\text { informacije sudionicima } \\
\text { savjetovanja. } \\
\text { Komentari podneseni } \\
\text { tijekom savjetovanja } \\
\text { trebaju biti dostupni } \\
\text { široj javnosti. } \\
\text { Potrebno je osigurati } \\
\text { povratne informacije } \\
\text { sudionicima o procesu } \\
\text { savjetovanja. } \\
\text { Građane je potrebno } \\
\text { dobro informirati } \\
\text { o učincima njihova } \\
\text { sudjelovanja. }\end{array}$ & $\begin{array}{l}\text { Kodeks, } \\
\text { čl. V. t. } 4 . \\
\\
\\
\\
\text { Smjernice } \\
\text { za } \\
\text { primjenu } \\
\text { članka } 11 . \\
\text { ZPPI-ja } \\
\text { Smjernice } \\
\text { za } \\
\text { primjenu } \\
\text { Kodeksa }\end{array}$ & $\begin{array}{l}\text { Nakon završenog } \\
\text { savjetovanja tijela javne } \\
\text { vlasti obvezna su objaviti } \\
\text { na središnjem portalu } \\
\text { ili internetskoj stranici } \\
\text { izvješće sa zaprimljenim } \\
\text { komentarima javnosti te } \\
\text { očitovanja s razlozima za } \\
\text { neprihvaćanje pojedinih } \\
\text { prijedloga i primjedbi. } \\
\text { Potrebno je javno objaviti } \\
\text { na internetskoj stranici ili } \\
\text { na drugi način pristigla } \\
\text { očitovanja zainteresirane } \\
\text { javnosti i objedinjeno } \\
\text { obrazloženje neprihvaćenih } \\
\text { primjedbi na odredbe nacrta. } \\
\text { Razuman rok za objavu } \\
\text { izvješća o provedenom } \\
\text { savjetovanju je } 30 \text { dana. } \\
\\
\text { Objava podnesenih } \\
\text { komentara i obrazloženja } \\
\text { neprihvaćenih primjedbi } \\
\text { od goruće je važnosti za } \\
\text { integritet i transparentnost } \\
\text { postupka savjetovanja } \\
\text { i motivaciju sudionika. } \\
\text { Predlaže se pažljivo } \\
\text { analizirati i “iskoristiti } \\
\text { prigodu da se ekspertiza, } \\
\text { iskustvo i stajališta } \\
\text { zainteresirane javnosti stave } \\
\text { u funkciju poboljšanja i } \\
\text { veće učinkovitosti odnosno } \\
\text { djelotvornosti određene } \\
\text { javne politike”. }\end{array}$ \\
\hline
\end{tabular}




\section{PROVEDBA SAVJETOVANJA S JAVNOŠĆU U PRAKSI HRVATSKIH UPRAVNIH ORGANIZACIJA}

\subsection{Provedba savjetovanja s javnošću - ocjena na temelju godišnjih izvješća Povjerenika za informiranje i Ureda za udruge Vlade RH}

Usprkos kontinuiranim poboljšanjima pravnog okvira te naporima relevantnih institucija, prije svega PI-ja kao nadzornog te UUVRH-a kao dosadašnjeg koordinativnog tijela na državnoj razini, nedostaci u njegovoj praktičnoj primjeni i dalje su prisutni. Njih je moguće evidentirati na temelju podataka godišnjih izvješća PI-ja o provedbi ZPPI-ja te UUVRH-a o provedbi Kodeksa. Iako je broj provedenih savjetovanja kontinuirano rastao iz godine u godinu, od $1454 \mathrm{u}$ 2015. godini do 4544 u 2018. godini (Slika 1), određene skupine tijela obveznika Zakona tu obvezu ne ispunjavaju u potpunosti ili u dostatnoj mjeri. Posebno se to odnosi na jedinice lokalne i područne (regionalne) samouprave (JLPRS) koje - iako su od 2015. do 2018. upeterostručile broj provedenih savjetovanja sa 604 na 3303 - još uvijek u značajnoj mjeri savjetovanja provode primarno za akte $\mathrm{u}$ područjima zaštite okoliša i prostornog uređenja, što predstavlja obvezu po posebnim propisima te dolazi do izostavljanja drugih općih akata i strateških dokumenata. Osim toga, značajan udio lokalnih jedinica uopće ne ispunjava obvezu provedbe savjetovanja - u 2016. 240, u 2017. 185, a u 2018. 54 gradova i općina nije provelo niti jedno savjetovanje, iako su donosili opće akte i planske dokumente. ${ }^{36}$ Kako je ocijenjeno na temelju analitičkog praćenja PI-ja provedbe savjetovanja od strane lokalnih jedinica u pet županija tijekom 2017., prikupljeni podaci upućuju na "izrazito nisku razinu provedbe savjetovanja s javnošću gotovo četiri godine nakon utvrđivanja navedene zakonske obveze”. ${ }^{37}$

I dok je iz Izvješća moguće identificirati probleme u pogledu ispunjavanja zakonske obveze provedbe savjetovanja, osobito na lokalnoj i regionalnoj razini, podaci o načinu, značajkama i rezultatima savjetovanja za tijela javne vlasti koja tu obvezu ispunjavaju dostupni su u načelnom i ograničenom opsegu. Jedan od problema koji se kontinuirano prepoznaje - iako je iz godine u godinu ostvaren

36 Na regionalnoj razini stanje je sljedeće: 2016. pet županija, 2017. četiri, 2018. tri županije nisu provele niti jedno savjetovanje. Riječ je o podacima iz Kumulativnog izvješća Povjerenika za informiranje o ispunjavanju obveza iz ZPPI-ja, https://www.pristupinfo.hr/djelokrug/otvoreni-podaci-povjerenika-za-informiranje/ (3. siječnja 2020.).

37 Izvješće Povjerenika za informiranje o provedbi Zakona o pravu na pristup informacijama za 2018. godinu, str. 64, https://www.pristupinfo.hr/wp-content/uploads/2019/04/1.-Izvje\%C5\%Al\%C4\%87e-o-provedbi-Zakona-o-pravu-na-pristup-informacijama-za-2018.pdf (3. siječnja 2020.). 
napredak - tiče se neispunjavanja zakonskog roka za provedbu savjetovanja u trajanju najmanje 30 dana, zatim objavljivanja godišnjeg plana savjetovanja ili njegovih izmjena te objave izvješća o provedenim savjetovanjima s pregledom pristiglih komentara i odgovorom na njih.

Nadalje, udio prihvaćenih komentara ne pokazuje tendenciju pada ili rasta, već ostaje na razini oko $25 \%$ prihvaćenih i djelomično prihvaćenih komentara. Ti podaci su, međutim, dostupni samo za državnu razinu, odnosno za tijela koja savjetovanja provode preko središnjeg portala eSavjetovanja, dok su podaci o stanju na lokalnoj i regionalnoj razini parcijalni. ${ }^{38}$ Nadalje, dostupni podaci (npr. o broju provedenih savjetovanja, trajanju savjetovanja, postotku prihvaćenosti komentara) su agregatne i načelne prirode te ne omogućavaju diferencijaciju prema različitim kategorijama upravnih organizacija ili drugim kriterijima. Stoga se u nastavku rada prikazuju nalazi empirijskog istraživanja savjetovanja s javnošću u Hrvatskoj provedenih u trogodišnjem razdoblju 2016. - 2018. godine, koji otkrivaju dublje uvide u stanje praktične primjene.

Slika 1. Porast broja provedenih savjetovanja sa zainteresiranom javnošću na razini tijela javne vlasti od 2015. do 2018. godine

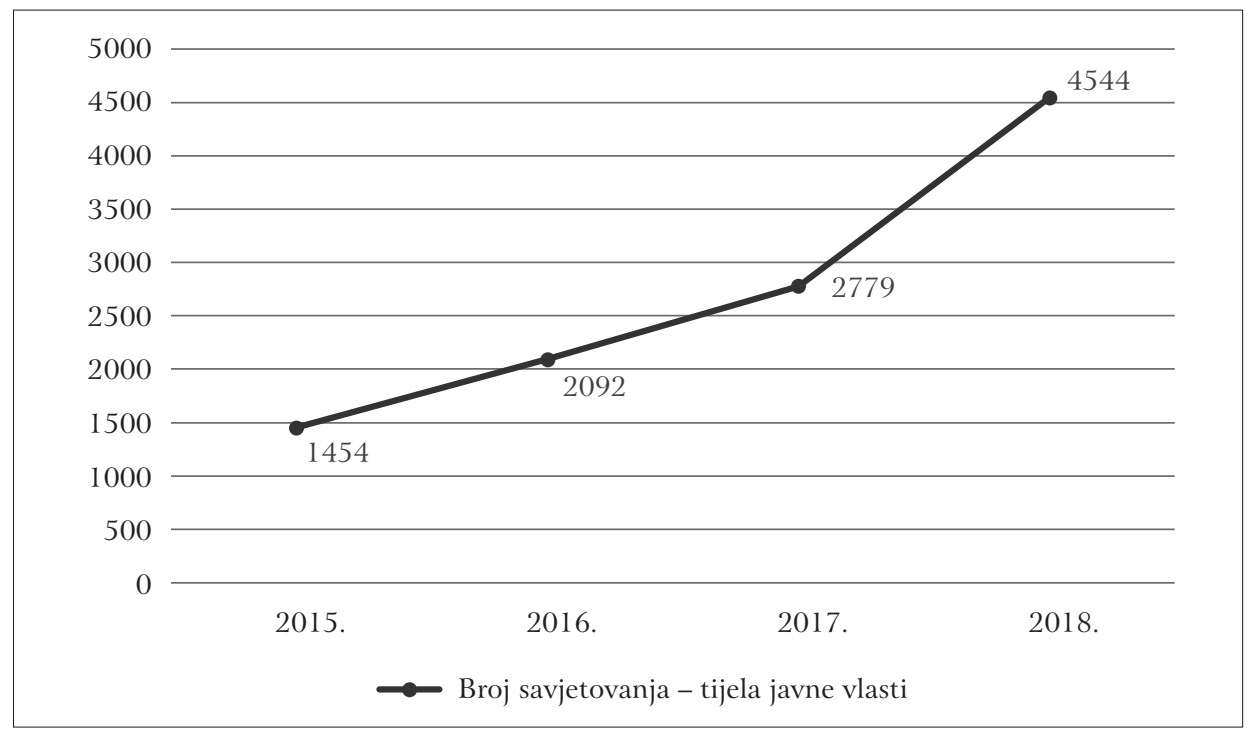

Izvor: autorica na temelju podataka godišnjih izvješća PI-ja za 2015., 2016., 2017. i 2018. godinu

38 Razlog je tome što UUVRH svojim praćenjem pokriva samo tijela državne razine, dok PI u okviru praćenja provedbe ZPPI-ja nadzire provedbu savjetovanja od strane svih tijela javne vlasti koja su na to obvezna, i to u smislu dostavljenih podataka od strane tijela javne vlasti, odnosno analize internetskih stranica određenih skupina tijela. 


\subsection{Provedba savjetovanja s javnošću - rezultati kvantitativne analize sadržaja izvješća o provedenim e-savjetovanjima od 2016. do 2018. godine}

\section{i. Metodologija i podaci}

U ocjeni stanja provedbe savjetovanja s javnošću u praksi RH koriste se empirijski podaci prikupljeni istraživačkom metodom kvantitativne analize sadržaja izvješća o provedenim e-savjetovanjima te popratnih dokumenata vezanih uz e-savjetovanja u trogodišnjem razdoblju od 2016. do 2018. godine. ${ }^{39}$ Istraživanje obuhvaća e-savjetovanja provedena od strane upravnih organizacija primarno regulativnog tipa na državnoj, regionalnoj i lokalnoj razini, pri čemu su isključena zakonodavna, sudbena, nadzorna i druga državna tijela, komore te široki spektar servisnih upravnih organizacija - javna poduzeća i ustanove. Primjenjujući kriterij minimalnog broja provedenih savjetovanja u trogodišnjem razdoblju (tri savjetovanja godišnje ili devet kumulativno), identificirane su upravne organizacije koje su provele dostatan broj savjetovanja ${ }^{40}$, na temelju čega je moguće izvoditi validne zaključke o načinu njihove provedbe. Preduvjet za analiziranje izvješća bila je njihova dostupnost na središnjem portalu eSavjetovanja (za upravne organizacije na državnoj razini), odnosno na internetskoj stranici tijela (za agencije i JLPRS ${ }^{41}$ ). Naposljetku se došlo do populacije analize sadržaja koju čine sva e-savjetovanja za koja su dostupna izvješća, provedena u razdoblju 2016. - 2018. od strane ukupno 132 tijela, od čega 19 ministarstava ${ }^{42}$,

39 Riječ je o dijelu istraživanja provedenoga 2018. i 2019. godine za potrebe izrade doktorske disertacije.

40 Ta su tijela identificirana na temelju kumulativnih izvješća tijela javne vlasti o provedbi ZPPI-ja za 2016., 2017. i 2018. godinu, objavljenih na internetskoj stranici Povjerenika za informiranje, https://www.pristupinfo.hr/djelokrug/otvoreni-podaci-povjerenika-za-informiranje/ (3. siječnja 2020.).

41 U slučaju gradova, općina i županija dostupnost dokumenata vezanih uz provedbu savjetovanja u značajnom opsegu pokazala se problematičnom. Za polovicu jedinica za koje je utvrđeno da zadovoljavaju kriterij broja provedenih e-savjetovanja na temelju podataka kumulativnih izvješća PI-ja pregledom njihovih internetskih stranica ustanovljeno je da nisu dostupni nikakvi podaci o provođenju savjetovanja ili nisu objavljena izvješća o provedenim savjetovanjima.

42 Sva ministarstva osim Ministarstva vanjskih i europskih poslova koje nije zadovoljilo brojčani kriterij provedenih savjetovanja. 
pet državnih upravnih organizacija ${ }^{43}$, šest agencija ${ }^{44}, 47$ gradova, 48 općina i sedam županija. ${ }^{45}$

Analizom izvješća o provedenim e-savjetovanjima - njih ukupno 4457 - prikupljeni su podaci o učestalosti provedbe savjetovanja, njihovu trajanju, jasnoći savjetovanja i prihvaćenosti komentara sudionika. Riječ je o standardima za provedbu savjetovanja s javnošću koji su sadržani u međunarodnim aktima i dokumentima te inkorporirani u hrvatsko zakonodavstvo, čime predstavljaju zakonsku obvezu za tijela javne vlasti. S druge strane, riječ je o pokazateljima kvalitete provedbe savjetovanja dobivenima primjenom kvantitativne istraživačke metode koja omogućuje formuliranje validnih zaključaka na temelju velikog broja prikupljenih podataka. Podaci o učestalosti, trajanju i jasnoći savjetovanja te prihvaćenosti komentara sudionika vidljivi su u izvješćima o provedenim e-savjetovanjima te popratnim dokumentima koji se objavljuju prilikom otvaranja e-savjetovanja na središnjem portalu (obrazloženja ciljeva i razloga donošenja ili izmjene akta). Zbog značajne razlike u rezultatima, nalazi istraživanja odvojeno se prikazuju za e-savjetovanja provedena na državnoj razini te na lokalnoj i regionalnoj razini ${ }^{46}$, dok se kod državne razine pravi dodatna distinkcija između tijela državne uprave (TDU) i agencija koje između sebe pokazuju značajnija odstupanja.

\section{ii. Učestalost provedbe e-savjetovanja}

Učestalost provedbe e-savjetovanja odnosi se na ukupan broj provedenih e-savjetovanja po upravnoj organizaciji. Na razini upravnih organizacija uključenih $\mathrm{u}$ istraživanje (132 tijela) JLPRS, gledano u apsolutnim brojevima, provele su gotovo dvostruko više e-savjetovanja (2813) nego TDU (1319) i agencije (324) na državnoj razini. Međutim, kada se broj provedenih e-savjetovanja ${ }^{47} \mathrm{u}$

43 Državna geodetska uprava, Državna uprava za zaštitu i spašavanje, Državni zavod za intelektualno vlasništvo, Državni zavod za mjeriteljstvo i Državni zavod za radiološku i nuklearnu sigurnost.

44 Hrvatska agencija za civilno zrakoplovstvo (HACZ), Hrvatska regulatorna agencija za mrežne djelatnosti (HAKOM), Hrvatska agencija za nadzor financijskih usluga (HANFA), Hrvatska energetska regulatorna agencija (HERA), Hrvatska narodna banka (HNB), Hrvatski zavod za zdravstveno osiguranje (HZZO).

45 Popis svih tijela uključenih u istraživanje nalazi se u Prilogu 1.

46 Zbog značajno manjeg broja analiziranih e-savjetovanja provedenih od strane županija, nalazi se prikazuju skupno za lokalnu i regionalnu razinu.

47 Broj e-savjetovanja o kojem se ovdje govori ne odgovora ukupnom broju e-savjetovanja koja su provela pojedina tijela jer određena vrsta akata za koja tijela provode 
analiziranom periodu stavi u odnos s brojem analiziranih tijela na državnoj, odnosno lokalnoj i regionalnoj razini, proizlazi da je prosječan broj provedenih e-savjetovanja po tijelu dvostruko manji na lokalnoj/regionalnoj razini (27) u odnosu na državnu (55) (Slika 2). Dakle, upravne organizacije na državnoj razini u prosjeku su provele 18 e-savjetovanja godišnje, a JLPRS 9.

Slika 2. Broj provedenih e-savjetovanja 2016. - 2018.

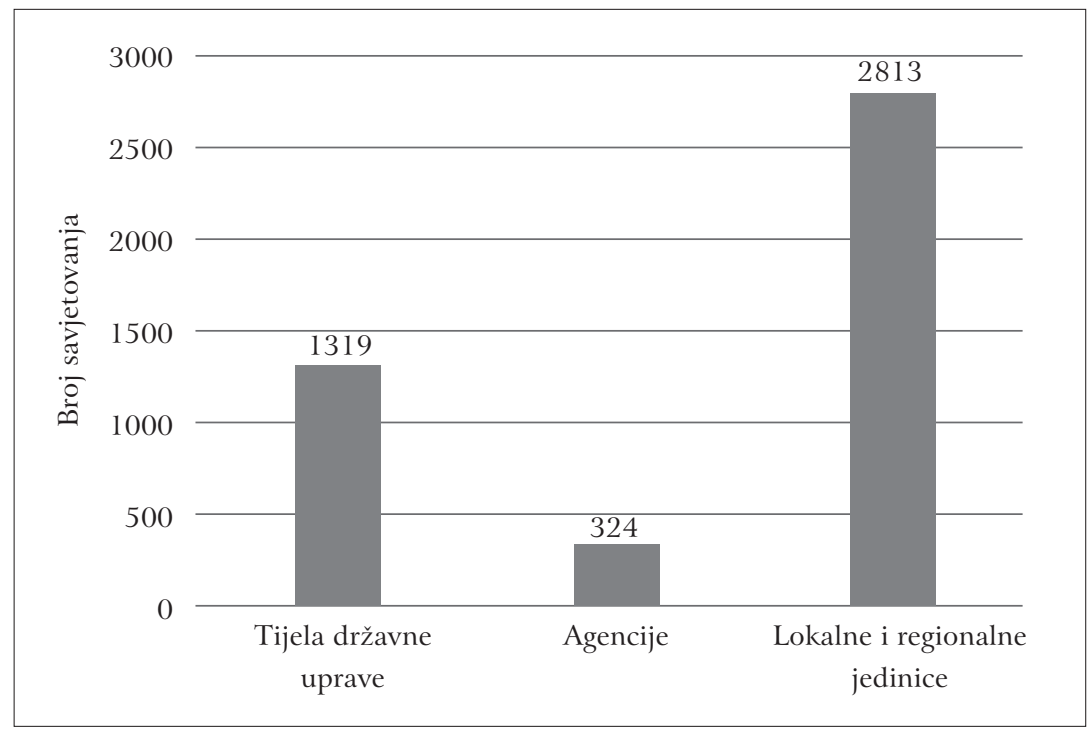

Značajne razlike u broju provedenih e-savjetovanja moguće je uočiti unutar pojedinih skupina tijela. Tako je, primjerice, Ministarstvo poljoprivrede u trogodišnjem razdoblju provelo 255 e-savjetovanja, a Ministarstvo državne imovine 13. Među agencijama se izdvaja HANFA s najvećim brojem provedenih savjetovanja (180) te HACZ s najmanjim (9). Kategorija DUO je prilično homogena s rasponom provedenih e-savjetovanja između 12 i 30. Vrlo velike razlike zamjećuju se unutar gradova; dok je, primjerice, Koprivnica provela 152 e-savjetovanja, nekoliko je gradova provelo samo devet e-savjetovanja u trogodišnjem razdoblju. Na lokalnoj razini samo je nekoliko gradova koji u analiziranom razdoblju imaju proveden broj e-savjetovanja koji značajno odstupa od prosjeka

e-savjetovanja nije uključena $u$ analizu (procjene učinaka propisa koje se provode prema posebnom zakonu i proceduri, zatim pojedinačni i interni akti za koje JLPRS ponekad provode savjetovanja iako za to ne postoji potreba u skladu sa ZPPI-jem). Osim toga, za određen broj e-savjetovanja u trenutku provedbe istraživanja nedostajala su izvješća te ona - radi metodološke dosljednosti - nisu uključena u ukupan broj provedenih e-savjetovanja. 
ostalih (27 u trogodišnjem razdoblju). ${ }^{48}$ Gradovi, u odnosu na općine, imaju u prosjeku nešto više provedenih e-savjetovanja - 32 je prosjek za gradove, a 24 za općine ${ }^{49} \mathrm{Za}$ županije taj je prosjek najmanji i iznosi 20 e-savjetovanja po jedinici regionalne samouprave. Naposljetku, vezano uz vrstu akta za koji se provodi e-savjetovanje, treba napomenuti kako je najveći broj e-savjetovanja, ukupno gledano, proveden za opće (38,2 \%) i strateško-planske akte $(28,2 \%)$ (lokalna i regionalna razina), nakon čega slijede pravilnici (18,7 \%) i zakoni (9\%), dok ostatak otpada na ostale podzakonske akte.

Broj provedenih e-savjetovanja izravno odražava regulativnu aktivnost pojedinih vrsta upravnih organizacija, koja proizlazi iz njihova Ustavom i zakonom definiranog djelokruga. U skladu s time, veća je produkcija pravnih propisa od strane TDU-a (posebno ministarstava) u odnosu na JLPRS. Vrlo velik broj e-savjetovanja nekolicine gradova i općina može se objasniti ponajprije učestalim izmjenama i dopunama općih akata i strateško-planskih dokumenata. Osobito je to slučaj kod onih jedinica koje provode zasebno e-savjetovanje za svaki program javnih potreba u različitim područjima (obrazovanju, kulturi, sportu itd.) i za njihove izmjene. Važno je napomenuti kako broj provedenih e-savjetovanja od strane pojedinih upravnih organizacija nije moguće izjednačiti s brojem ukupno donesenih akata jer upravne organizacije - ponajprije na državnoj razini - ipak ne provode savjetovanja za sve akte. ${ }^{50}$

\section{iii. Trajanje e-savjetovanja}

Trajanje e-savjetovanja mjerilo se ukupnim brojem dana tijekom kojih je ono bilo otvoreno za podnošenje komentara od strane javnosti. Trajanje e-savjetovanja nešto je duže na državnoj u odnosu prema lokalnoj/regionalnoj razini

$48 \mathrm{Uz}$ spomenutu Koprivnicu velikim brojem e-savjetovanja još se izdvajaju Ivanec (109), Varaždinske Toplice (92) i Lepoglava (81).

49 Većim brojem provedenih e-savjetovanja među općinama ističu se Kistanje (93), Kloštar Ivanić (90) i Konavle (72).

50 To pitanje izlazi izvan okvira postavljenoga empirijskog istraživanja, zbog čega se nije istraživala razlika u ukupno donesenim aktima i provedenim e-savjetovanjima. Međutim, na temelju analitičkih praćenja u godišnjim se izvješćima PI-ja ustvrđuje da su u 2017. provedena savjetovanja za otprilike $45 \%$ akata za koje je postojala obveza provedbe savjetovanja. Pritom je najveći udio savjetovanja proveden za zakone, strategije i programe (67\%), a najmanji za odluke (11 \%) (PI, 2018: 63). Iako se savjetovanja ne moraju provoditi za sve akte, poput internih ili onih s isključivo tehničkim izmjenama, tijela ponekad propuštaju provesti savjetovanja i u slučajevima akata kojima se utječe na interese javnosti, najčešće zbog primjene hitnog postupka. 
te kod agencija u odnosu na TDU ako se gleda samo državna razina. Razlika ipak nije velika, osobito između TDU-a (24,4 dana u prosjeku) i agencija $(26,4$ dana) (Slika 3). Na državnoj razini, primjerice, od prosjeka ostalih upravnih organizacija odskače Ministarstvo znanosti i obrazovanja s prosječnim trajanjem e-savjetovanja od 66 dana, zbog prijedloga kurikuluma za koja su savjetovanja bila otvorena 115 ili više dana.

Slika 3. Prosječno trajanje e-savjetovanja po tijelima (u danima)

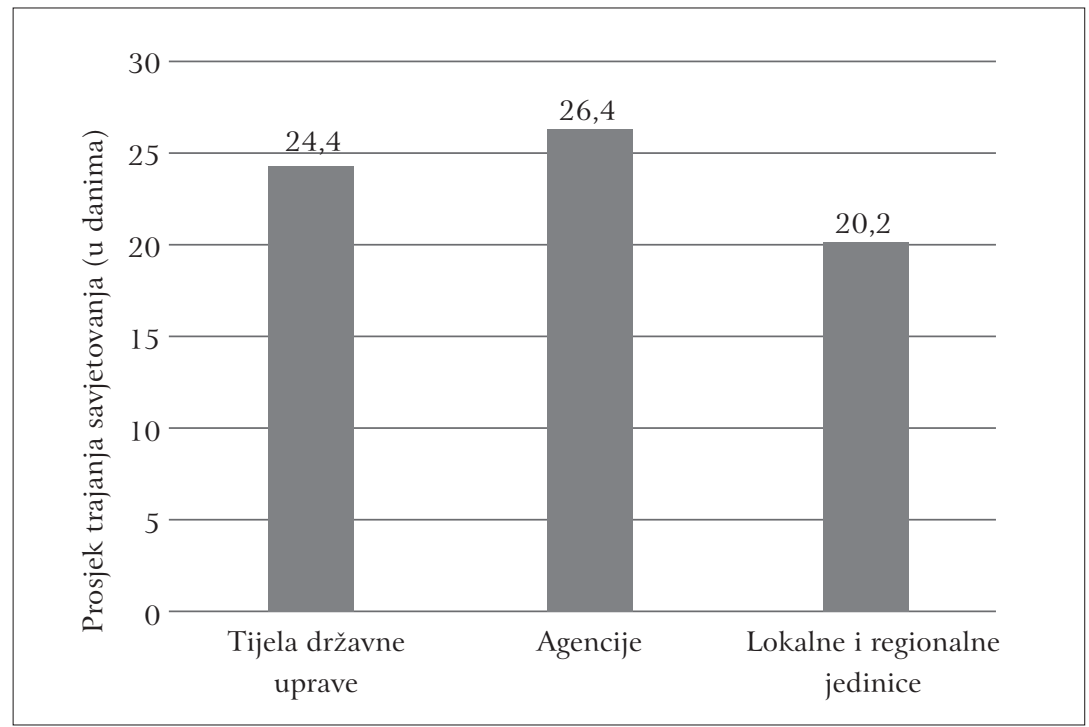

Iako se ne pokazuje značajnija razlika, e-savjetovanja za strateško-planske akte traju duže (24 dana u prosjeku) u odnosu na druge, osobito opće akte na lokalnoj i regionalnoj razini, za koje savjetovanja prosječno traju 20 dana. Taj nalaz može se objasniti time što strategije, planovi i programi nisu obvezujuće prirode te kod njih ne postoji tako jak pritisak prema bržem postupku donošenja radi ispunjavanja proceduralnih rokova kao što je to kod zakona, podzakonskih i općih akata, kod kojih procedura donošenja, sjednice Vlade i lokalnih predstavničkih tijela često diktiraju rokove. Na lokalnoj razini 14,1 \% e-savjetovanja traje kraće od osam dana. Od svih analiziranih e-savjetovanja zakonsku obvezu u pogledu trajanja minimalno 30 dana ispunjava njih 37,8 \% (41,4 \% na državnoj i 35,7 \% na lokalnoj/regionalnoj razini). 


\section{iv. Jasnoća e-savjetovanja}

Jasnoća procesa e-savjetovanja procjenjivala se na temelju objavljenih obrazloženja prilikom otvaranja e-savjetovanja o razlozima i ciljevima koji se žele ostvariti donošenjem ili izmjenom akta te obrazlaganjem njegova sadržaja. Jasnoća e-savjetovanja procjenjivala se na četiri razine, od najniže u slučajevima kada obrazloženje ne postoji (razina l), preko postojanja rudimentarnog obrazloženja s vrlo šturim informacijama o razlozima provedbe savjetovanja (razina 2), do djelomičnog obrazloženja kada je obrazloženje iscrpnije, ali ne i potpuno (razina 3), što predstavlja najvišu, četvrtu razinu jasnoće (razina 4). Pokazuje se kako je pitanje jasnoće e-savjetovanja općenito slaba točka u njihovoj provedbi. Iznimku predstavljaju agencije koje u prosjeku objavljuju detaljnija obrazloženja uz nacrte propisa. Kada se u obzir uzme medijalna vrijednost, lokalna i regionalna razina ima veći medijan jasnoće (2) u odnosu na državnu (koja uključuje TDU i agencije) kod koje je najčešća medijalna vrijednost jasnoće e-savjetovanja ministarstava l, tj. najniža razina kod koje nedostaje obrazloženje (Tablica 2). JLPRS često izostavljaju obrazloženja razloga i ciljeva općih akata i strateških i planskih dokumenata ili, još češće, daju vrlo rudimentarna objašnjenja koja se sastoje samo od navođenja zakona na temelju kojeg se donosi akt za koji se provodi savjetovanje ili se samom nazivu akta dodaje pokoja riječ ili vrlo općenita rečenica.

\section{Tablica 2. Jasnoća e-savjetovanja}

\begin{tabular}{|l|c|c|}
\hline vrsta upravne organizacije & medijan & srednja vrijednost \\
\hline tijela državne uprave & 1 & 1,5 \\
\hline agencije & 4 & 3,2 \\
\hline lokalne i regionalne jedinice & 2 & 1,9 \\
\hline
\end{tabular}

*Legenda: I-nema obrazloženja, 2-rudimentarno obrazloženje, 3-djelomično obrazloženje, 4-potpuno obrazloženje

Naposljetku, s razinom jasnoće pokazuje se povezana vrsta akta - proces e-savjetovanja jasniji je kod zakona u odnosu na druge podzakonske, strateško-planske i opće akte jedinica lokalne i regionalne samouprave. Zbog poslovničkog postupka nacrti zakona u pravilu sadržavaju ustavnu osnovu donošenja u okviru koje se, više ili manje detaljno, objašnjavaju razlozi i ciljevi donošenja zakonskog akta. S druge strane, kod pravilnika ministarstava takva obrazloženja mahom izostaju ili su ona vrlo rudimentarna. Naime, službenici često smatraju da kod takvih, nižih propisa ne postoji potreba za posebnim obrazloženjima jer se navodi na temelju kojeg zakona se donose. Iako unutar uvodnog dijela strateško-planski akti navode opće ciljeve, ciljane skupine i sl., u pravilu se ne 
objavljuje popratni dokument sa sumiranim obrazloženjem ili standardni obrazac za savjetovanje, što je razlog njihove niže razine jasnoće.

\section{v. Prihvaćenost komentara}

Prihvaćenost komentara pokazuje postotak komentara sudionika koji su od strane upravne organizacije nakon provedenog e-savjetovanja označeni statusom prihvaćeni ili djelomično prihvaćeni. Status komentara sudionika u izvješćima može biti naveden kao prihvaćen, djelomično prihvaćen, odbijen ili primljen na znanje. Gledano agregatno za sve analizirane upravne organizacije, najveći postotak komentara sudionika se odbija (više od 40 \% komentara), dok se postotak prihvaćenih (potpuno ili djelomično) komentara razlikuje na državnoj i lokalnoj/regionalnoj razini (Slika 4 i 5). Na državnoj razini postotak prihvaćenih komentara iznosi 23,8 \% (15,7 \% prihvaćenih i 8,1 \% djelomično prihvaćenih), dok je odbijenih 43,5 \% te 28,1 \% primljenih na znanje. Na lokalnoj/regionalnoj razini postotak prihvaćenosti komentara je veći i iznosi 35,8 \%, od čega je $24,8 \%$ prihvaćenih i $11 \%$ djelomično prihvaćenih. Odbijenih je komentara $41,4 \%$, a primljenih na znanje 22,7 \%. Nalaz o većoj responzivnosti uprave prema građanima na nižim razinama političko-upravnog sustava u skladu je s prevladavajućom tezom u literaturi o većoj usmjerenosti nižih razina vlasti na potrebe građana i njezinoj prikladnosti za participaciju. ${ }^{51}$

\section{Slika 4. Status komentara na državnoj razini (u postotku)}

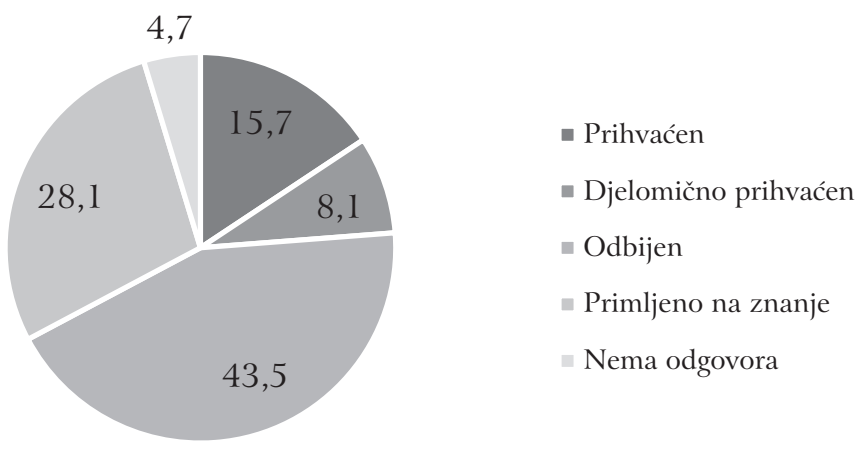

51 Koprić, I.; Marčetić, G.; Musa, A.; Đulabić, V.; Lalić Novak, G., Upravna znanost Javna uprava u suvremenom europskom kontekstu, Pravni fakultet Sveučilišta u Zagrebu, Zagreb, 2014., str. 255; Burton, P., Conceptual, Theoretical and Practical Issues in Measuring the Benefits of Public Participation, Evaluation, vol. 15, br. 3, 2009., str. 269 - 270; vidi i Gaster, L., Participation and local government, u: Douglas, L. N.; Campbell, D. (ur.), Promoting Participation: Law or Politics?, Cavendish Publishing Limited, London, 1999. 
Slika 5. Status komentara na lokalnoj/regionalnoj razini (u postotku)

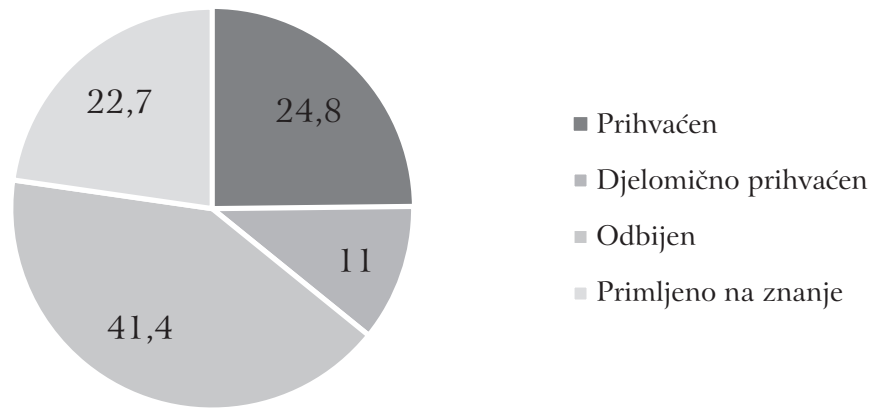

Razlika u prihvaćenosti komentara pokazuje se i između različitih vrsta upravnih organizacija na državnoj razini (Slika 6). Komentare sudionika u većoj mjeri prihvaćaju upravne organizacije agencijskog tipa u odnosu na klasična ministarstva. ${ }^{52} \mathrm{Za}$ objašnjenje razlike u razini prihvaćenosti komentara kod različitih vrsta upravnih organizacija potrebno je uzeti u obzir "izvanjski” čimbenik samih sudionika, odnosno zainteresirane javnosti koja se uključuje u postupak e-savjetovanja. Naime, agencije uglavnom dobivaju komentare užeg kruga zainteresirane javnosti, na koju se propisi izravno odnose, tj. koji ih primjenjuju. Oni predstavljaju izravne korisnike, odnosno regulirane subjekte koji upućuju i kvalitativno drukčije komentare, koji su regulatornim agencijama potrebni i korisni, često stručnog karaktera. S druge strane, u slučaju ministarstava ta je javnost fragmentirana te se i sami komentari kvalitativno razlikuju od onih u slučaju agencija. Faktor vrste sudionika i komentara potrebno je uzeti u obzir i pri interpretaciji prihvaćenosti komentara na lokalnoj/regionalnoj razini, pri čemu zainteresirana javnost u većoj mjeri upućuje opća mišljenja i stavove (u odnosu na argumentirane i tehničke komentare) koji se u većoj mjeri i prihvaćaju, s obzirom na to da je riječ o teritorijalno najbližoj razini koja odlučuje o pitanjima važnima za svakodnevni život lokalnog stanovništva. ${ }^{53}$

52 Formalno se DUO razmatraju unutar kategorije TDU, iako je riječ o svojevrsnim hibridnim organizacijama koje pokazuju određena agencijska obilježja (v. Musa, A., Agencijski model javne uprave, Pravni fakultet Sveučilišta u Zagrebu, Studijski centar za javnu upravu i javne financije, Zagreb, 2014, str. 438 - 446). Stoga ne čudi nalaz o većoj razini prihvaćenosti komentara kod DUO u odnosu prema ministarstvima.

53 Više o utjecaju čimbenika vezanih za broj i vrstu sudionika i njihovih komentara na razinu prihvaćanja komentara u postupcima e-savjetovanja u Hrvatskoj u Đurman, P., Utjecaj organizacijskih varijabli na proces i rezultate participacije u javnoj upravi, doktorska disertacija, Pravni fakultet Sveučilišta u Zagrebu, Zagreb, 2019. 
Slika 6. Usporedba statusa komentara TDU i agencija (u postotku)

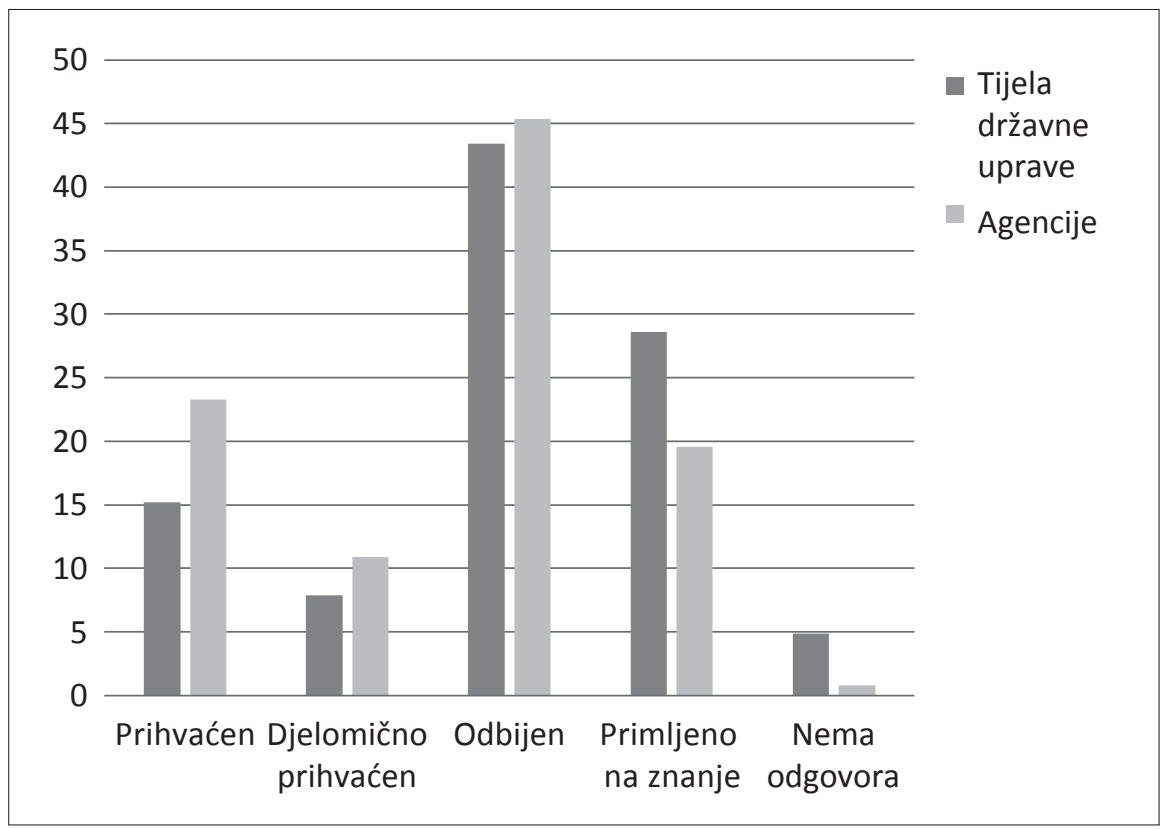

\section{RASPRAVA I ZAKLJUČNA RAZMATRANJA}

Načela participacije, inkluzivnosti i responzivnosti postala su sastavni segment donošenja odluka i oblikovanja javnih politika i propisa u suvremenim demokratskim državama, a savjetovanja s javnošću uobičajeni instrument njihova ostvarivanja u praksi. Budući da savjetovanja s javnošću, u svojoj elektroničkoj inačici, u RH predstavljaju novitet koji nije dovoljno znanstveno istražen, cilj je ovog rada bio analizirati (e-)savjetovanja u dva aspekta; ponajprije u pogledu pravne usklađenosti s međunarodnim standardima, a zatim u pogledu njihove praktične primjene.

Analiza pravnog okvira upozorila je na usklađenost normativnog okvira za provedbu savjetovanja s javnošću u RH sa standardima međunarodnih dokumenata. Standardi o jasnoći i trajanju savjetovanja, obavještavanju javnosti o provedbi savjetovanja, pravodobnom uključivanju javnosti, upućivanju povratne informacije javnosti nakon provedenog savjetovanja, važnosti predanosti i osposobljenosti službenika za provedbu savjetovanja te o korištenju višestrukih i online instrumenata participacije sadržani su u temeljnim predmetnim aktima ZPPI-ju i Kodeksu savjetovanja te, dodatno, u smjernicama za njihovu provedbu. Sukladno tome, moguće je konstatirati kako je pravni okvir za provedbu 
savjetovanja zadovoljavajući. Detaljnije normiranje pojedinih aspekata načina provedbe savjetovanja nije potrebno, a niti poželjno, već je pažnju potrebno usmjeriti na provedbu savjetovanja s javnošću u praksi.

U izgradnji normativne infrastrukture za provedbu savjetovanja s javnošću u Hrvatskoj moguće je izdvojiti tri ključna događaja s vrlo važnim praktičnim implikacijama. Prvo, Kodeks savjetovanja koji je Vlada RH usvojila 2009., kao prvi akt koji je normirao provedbu savjetovanja s javnošću, bio je donesen u kontekstu europeizacijskih procesa i utjecaja. Savjetovanja su došla na političku agendu donošenjem Akcijskog plana uz Strategiju suzbijanja korupcije 2008.54 jer je jedno od gorućih pitanja procesa pristupanja EU-u bila borba protiv korupcije. ${ }^{55}$ Iako je Kodeks imao važnu ulogu u uvođenju standarda savjetovanja u praksu upravnih organizacija - što je evidentno i u pozivanju na njegove odredbe i nakon stupanja na snagu pravno nadređenih odredbi ZPPI-ja - kao pravno neobvezujući akt nije doveo do značajnijeg prihvaćanja postupka savjetovanja od strane upravnih organizacija, ni na državnoj, a još manje na lokalnoj i regionalnoj razini. Usto, jedan je od njegovih bitnijih nedostataka usmjerenost na upravne organizacije središnje državne razine što se, u smislu prakse provedbe savjetovanja, sigurno odrazilo na stanje na lokalnoj i regionalnoj razini. Ipak, donošenje Kodeksa utrlo je put daljnjem razvoju normativnog okvira kroz inkorporiranje procedure savjetovanja u odredbe Poslovnika Sabora i Vlade RH, donošenje novog ZPPI-ja itd., dok se u praktičnom pogledu pristupilo promociji procedure savjetovanja te educiranju upravnih službenika (u TDU imenovani su koordinatori za savjetovanja radi ujednačavanja provedbe savjetovanja te su pokrenute edukacije službenika za rad u skladu s novom praksom).

Drugi ključan normativni događaj bilo je propisivanje zakonske obveze provedbe savjetovanja ZPPI-jem iz veljače 2013. Krucijalna zakonska novina bilo je uvođenje PI-ja, središnje institucije nadležne za nadzor nad provođenjem odredbi Zakona. Novim je Zakonom provedba savjetovanja postala pravno obvezatna te je predviđen institucionalni okvir u vidu specijalizirane vrste ombudsmana za

54 Narodne novine, br. 75/2008.

55 U okviru poglavlja 23. o pravosuđu i temeljnim slobodama bile su potrebne mnogobrojne prilagodbe, koje su se tijekom pregovora, ali i nakon njihova zatvaranja $\mathrm{u}$ razdoblju tzv. monitoringa (nadzornog mehanizma), manifestirale $\mathrm{u}$ donošenju i izmjenama brojnih zakona radi usklađivanja s pravnom stečevinom EU-a, što se najčešce činilo po hitnoj proceduri. Vidi Đurman, P., Europeizacija javne uprave i načelo otvorenosti, Godišnjak Akademije pravnih znanosti Hrvatske, vol. 7, br. 1, 2016. str. 347. Šire o utjecaju europeizacije na javnu upravu u RH vidi Koprić, I., Prilagodbe hrvatske javne uprave europskim standardima, u: Koprić, I. (ur.), Europeizacija hrvatske javne uprave, Pravni fakultet Sveučilišta u Zagrebu i Studijski centar za javnu upravu i javne financije, Zagreb, 2014., str. 3 - 32. 
praćenje zakonskih odredbi, koji je zaživio nakon nekoliko mjeseci, u listopadu 2013. Tom je institucionalnom nadogradnjom slovo zakona dobilo, s jedne strane, "batinu" - budući da Zakon predviđa mogućnost izricanja kazni u slučaju kršenja njegovih odredbi, dok je, s druge strane, osiguran temeljni mehanizam promocije i educiranja upravnih službenika u vezi s provedbom savjetovanja.

Kao treći važan normativni događaj izdvajaju se odluke Ustavnog suda iz 2013. kojima su ukinuta dva podzakonska akta Ministarstva znanosti, obrazovanja i sporta. Ustavni je sud time poslao jasnu poruku tijelima državne uprave o nužnosti demokratične procedure koja uključuje javnu raspravu pri donošenju svakog akta koji je od interesa javnosti.

Usprkos značajnom napretku koji je ostvaren posljednjih nekoliko godina u provedbi e-savjetovanja, rezultati empirijskog istraživanja upućuju na nekoliko problematičnih aspekata. Ponajprije, savjetovanja se u značajno većem broju provode na državnoj razini, dok JLPRS u tome "kaskaju". Iako učestalost provedbe e-savjetovanja izravno ovisi o normativnom djelokrugu upravne organizacije, njihova provedba ipak češće izostaje na lokalnoj i regionalnoj razini. Manji broj gradova i općina po broju provedenih e-savjetovanja u analiziranom razdoblju značajno odstupa, no razlog tome leži u brojnim i učestalim izmjenama i dopunama općih akata i strateško-planskih dokumenata. Nadalje, e-savjetovanja uglavnom ne traju u zakonski predviđenom roku od 30 dana te se taj rok nerijetko skraćuje mimo opravdanih razloga, pogotovo na lokalnoj i regionalnoj razini. Jasnoća savjetovanja pokazala se slabom karikom provedbe e-savjetovanja i na državnoj razini, na kojoj za većinu nacrta akata (osobito za pravilnike) izostaje objašnjenje razloga i ciljeva zbog kojih se akt donosi, i na lokalnoj/regionalnoj razini, na kojoj su ta obrazloženja najčešće vrlo rudimentarna.

U pogledu prihvaćenosti komentara javnosti - koja za sve uključene upravne organizacije u prosjeku iznosi četvrtinu komentara - bitnima se pokazuju tri čimbenika. Prvi je razina vlasti, pri čemu je responzivnost veća na lokalnoj/ regionalnoj razini (35,8 \% prihvaćenih i djelomično prihvaćenih komentara) u odnosu na državnu (23,8 \% prihvaćenih i djelomično prihvaćenih komentara). Takav nalaz u skladu je s tezama o prikladnosti nižih, građanima teritorijalno bližih, razina vlasti za participaciju javnosti i usmjerenosti na ostvarivanje potreba i interesa lokalne zajednice. Ipak, taj demokratski potencijal na koji upućuju rezultati istraživanja nije $\mathrm{u}$ dostatnoj mjeri iskorišten zbog vrlo niske razine uključivanja javnosti u e-savjetovanja na lokalnoj i regionalnoj razini. Drugi čimbenik odnosi se na vrstu upravnih organizacija. Naime, responzivnost prema komentarima javnosti veća je i u slučaju agencija u odnosu prema klasičnim upravnim organizacijama, tj. TDU. Konačno, nužno je upozoriti na relevantnost "izvanjskog” čimbenika - zainteresirane javnosti koja se uključuje u proces e-sa- 
vjetovanja. Naime, broj i vrsta sudionika (građani pojedinci, interesne udruge, privatni sektor, druga državna i javna tijela itd.) te sadržaj njihovih komentara variraju ovisno o vrsti upravne organizacije koja provodi e-savjetovanje, vrsti i temi akta (koja se odražava na njegovu političku osjetljivost, ciljane skupine, medijsku eksponiranost itd.). U tom kontekstu veća razina prihvaćenosti komentara na lokalnoj/regionalnoj razini u odnosu na državnu, te kod agencija u odnosu na TDU, velikim dijelom proizlazi iz strukture podnositelja komentara i vrste njihovih komentara. ${ }^{56}$

$\mathrm{Na}$ temelju iznesenoga moguće je iznijeti osnovne preporuke za provedbu e-savjetovanja u praksi. Prvo, upravne organizacije trebale bi biti dosljedne $u$ provedbi e-savjetovanja za one akte za koje postoji obveza. Drugo, potrebno je poštovati zakonski rok od 30 dana tijekom kojih e-savjetovanje mora biti otvoreno. Iznimke koje uključuju tehničke izmjene i izvanredne okolnosti ne smiju biti široko tumačene i ekstenzivno primjenjivane. Vremenski problem poštovanja rokova za upućivanje akata u daljnju proceduru može se nadvladati pažljivijim planiranjem normativnog procesa u organizaciji. Dakle, e-savjetovanja treba na vrijeme predvidjeti i ukomponirati kao sastavni i uobičajeni dio regulacijskog procesa. Treće, puno više pažnje treba se posvećivati kvalitetnijim obrazloženjima uz svaki nacrt akta za koji se provodi e-savjetovanje. Riječ je o posebnom obrazloženju razloga i ciljeva koji se žele postići donošenjem propisa, što predstavlja obvezu sukladno ZPPI-ju (čl. 11. st. 2.). Posebno je to važno za pravilnike koji predstavljaju temeljne provedbene akte, a za njih takva obrazloženja mahom izostaju. Četvrto, potrebno je predvidjeti i dostatan period i broj službenika koji rade na obrađivanju zaprimljenih komentara kako bi se osigurao kvalitetan proces analize svih primjedbi i sugestija. S tim u vezi potrebna je daljnja kontinuirana edukacija i osposobljavanje službenika, ne samo u vezi s tehničkim i sadržajnim elementima vezanim uz provedbu savjetovanja, već i u pogledu promjene načina percipiranja savjetovanja - manje kao formalne obveze, a više kao procesa koji omogućava veću kvalitetu i dugotrajnost regulacije.

\section{LITERATURA}

Bugarič, B., Openness and Transparency in Public Administration: Challenges for Public Law, Wisconsin International Law Journal, vol. 22, br. 3, 2004., str. 483-521.

Burton, P., Conceptual, Theoretical and Practical Issues in Measuring the Benefits of Public Participation, Evaluation, vol. 15, br. 3, 2009., str. 263-284, doi. org/10.1177/1356389009105881

56 Više u: Đurman, op. cit. u bilj. 51. 
Đurman, P., Utjecaj organizacijskih varijabli na proces i rezultate participacije u javnoj upravi, doktorska disertacija, Pravni fakultet Sveučilišta u Zagrebu, Zagreb, 2019.

Đurman, P., Europeizacija javne uprave i načelo otvorenosti, Godišnjak Akademije pravnih znanosti Hrvatske, vol. 7, br. 1, 2016., str. 342-373.

Fuchs, D., Participatory, liberal and electronic democracy, u: Zittel, T.; Fuchs, D. (ur.), Participatory Democracy and Political Participation: Can participatory engineering bring citizens back in?, Taylor i Francis, New York, 2007., str. 29-55, doi. org/10.4324/9780203969311

Gaster, L., Participation and local government, u: Douglas, L. N.; Campbell, D. (ur.), Promoting Participation: Law or Politics?, Cavendish Publishing Limited, London, 1999., str. 113-135.

Koprić, I., Demokracija, decentralizacija, povjerenje građana i ponos javnih službenika: stari i novi koncepti u razvoju odnosa građana i javne uprave, u: Koprić, I.; Musa, A.; Giljević, T. (ur.), Građani, javna uprava i lokalna samouprava: povjerenje, suradnja, potpora, Institut za javnu upravu, Zagreb, 2017., str. 3-27.

Koprić, I., Prilagodbe hrvatske javne uprave europskim standardima, u: Koprić, I. (ur.), Europeizacija hrvatske javne uprave, Pravni fakultet Sveučilišta u Zagrebu i Studijski centar za javnu upravu i javne financije, Zagreb, 2014., str. 3-32.

Koprić, I.; Marčetić, G.; Musa, A.; Đulabić, V.; Lalić Novak, G., Upravna znanost - Javna uprava u suvremenom europskom kontekstu, Pravni fakultet Sveučilišta u Zagrebu, Zagreb, 2014.

Musa, A., Informacije za građane: transparentnom i otvorenom javnom upravom prema boljem upravljanju i povjerenju građana, u: Koprić, I.; Musa, A.; Giljević, T. (ur.), Građani, javna uprava i lokalna samouprava: povjerenje, suradnja, potpora, Institut za javnu upravu, Zagreb, 2017., str. 29-72.

Musa, A., Pravni i institucionalni aspekti prava na pristup informacijama i transparentnosti u Republici Hrvatskoj, u: Arbutina, H., Rogić Lugarić, T. (ur.), Spomenica prof. dr. sc. Juri Šimoviću, Pravni fakultet Sveučilišta u Zagrebu, Zagreb, 2017., str. 421-488.

Musa, A., Agencijski model javne uprave, Pravni fakultet Sveučilišta u Zagrebu, Studijski centar za javnu upravu i javne financije, Zagreb, 2014.

Musa, A., Transparentnost - kako i zašto?, u: 5. Forum za javnu uрravu, Institut za javnu upravu i Fridrich Ebert Zaklada, Zagreb, 2013., str. 7-26.

Musa, A.; Dobrić Jambrović, D., Participacija na lokalnoj razini kao standard Vijeća Europe: uloga Europske povelje o lokalnoj samoupravi i Protokola o pravu na sudjelovanje u poslovima lokalnih vlasti, u: Koprić, I. (ur.), Europeizacija hrvatske lokalne samouprave: Dva desetljeća primjene Europske povelje o lokalnoj samoupravi, Institut za javnu upravu, Zagreb, 2018., str. 272-342. 
Musa, A.; Vidačak, I.; Volmut, I; Pernar, S., Priručnik za provedbu savjetovanja s javnošću za jedinice lokalne i područne (regionalne) samouprave, Povjerenik za informiranje, Zagreb, 2016.

OECD, Better Regulation Practices across the European Union, OECD Publishing, Paris, 2019., http://www.oecd.org/publications/better-regulation-practices-across-the-european-union-9789264311732-en.htm (30. ožujka 2020.), doi.org/10.1787/9789264311732-en

OECD, Građani kao partneri: Informiranje, konzultiranje i participiranje javnosti u kreiranju provedbene politike, Oksimoron, Zagreb (hrvatski prijevod), 2004.

Ofak, L., Application of the Aarhus Convention in Southeast Europe, u: Rodin, S.; Perišin, T. (ur.), Judicial Application of International Law in Southeast Europe, Springer, Heidelberg, New York, Dordrecht, London, 2015., str. 43-62, doi. org/10.1007/978-3-662-46384-0

Ofak, L., Sudjelovanje javnosti u odlučivanju u pitanjima okoliša, Hrvatska javna uprava: časopis za teoriju i praksu javne uprave, vol. 9, br. 2, 2009., str. 443-470.

Pina, V.; Torres, L., The Managers' View of Participation Processes with Citizen Panels, u: Aichholzer, G.; Kubicek, H.; Torres, L. (ur.), Evaluating e-Participation: Frameworks, Practice, Evidence, Springer, London, 2016., str. 289-306, doi. org/10.1007/978-3-319-25403-6

Popelier, P., Management of Legislation, u: Karpen, U.; Xanthaki, H. (ur.), Legislation in Europe: A Comprehensive Guide for Scholars and Practitioners, Hart Publishing, Oxford, Portland, 2017., str. 53-72, doi.org/10.1080/20508840.2017.1364074

Rowe, G.; Frewer, L. J., A Typology of Public Engagement Mechanisms, Science, Technology \& Human Values, vol. 30, br. 2, 2005., str. 251-290, doi. org/10.1177/0162243904271724

Shulman, S. W., eRulemaking: Issues in Current Research and Practice, eRulemaking Research Group, 2005., str. 621-641, https://scholarworks.umass.edu/erulemaking/4, doi.org/10.1081/PAD-200064221

Tomkova, J., E-consultations: New tools for civic engagement or facades for political correctness?, European Journal of ePractice, br. 7, 2009., str. 1-10, http://citeseerx. ist.psu.edu/viewdoc/download?doi=10.1.1.466.7291 \& rep=repl\&type $=$ pdf

Wang, X.; Wan Wart, M., When Public Participation in Administration Leads to Trust: An Empirical Assessment of Managers' Perceptions, Public Administration Review, vol. 67, br. 2, 2007., str. 265-278, doi.org/10.1111/j.1540-6210.2007.00712.x 


\section{PRAVNI IZVORI}

\section{Hrvatski pravni propisi, dokumenti i izvješća}

Ustav Republike Hrvatske (NN 56/90, 135/97, 08/98, 113/00, 124/00, 28/01, 41/01, 55/01, 76/10, 85/10, 05/14).

Zakon o pravu na pristup informacijama (NN 25/13, 85/15).

Zakon o procjeni učinaka propisa (NN 44/17).

Zakon o zaštiti okoliša (NN 80/13, 153/13, 78/15, 12/18, 118/18).

Zakon o prostornom uređenju (NN 153/13, 65/17, 114/18, 39/19).

Zakon o održivom gospodarenju otpadom (NN 94/13, 73/17, 14/19).

Poslovnik Vlade RH (NN 154/11, 121/12, 7/13, 61/15, 99/16, 57/17).

Poslovnik Hrvatskog sabora (NN 81/13, 113/16, 69/17, 29/18).

Uredba o provedbi postupka procjene učinaka propisa (NN 52/17).

Ustavni sud RH, U-II-1118/2013 od 22. svibnja 2013. (NN 63/13).

Ustavni sud RH, U-II-1304/2013. od 16. srpnja 2013. (NN 99/13).

Kodeks savjetovanja sa zainteresiranom javnošću u postupcima donošenja zakona, drugih propisa i akata (NN 140/2009).

Strategija suzbijanja korupcije (NN 75/2008).

Ministarstvo pravosuđa RH, Akcijski plan uz Strategiju suzbijanja korupcije (NN 75/2008), lipanj 2008.

Povjerenik za informiranje, Smjernice za primjenu članka 11. Zakona o pravu na pristup informacijama (NN 25/13 i 85/15) - savjetovanja s javnošću.

Ured za udruge Vlade RH, Smjernice za primjenu Kodeksa savjetovanja sa zainteresiranom javnošću u postupcima donošenja zakona, drugih propisa i akata.

Povjerenik za informiranje, Izvješće Povjerenika za informiranje o provedbi Zakona o pravu na pristup informacijama za 2018. godinu, ožujak 2019.

Povjerenik za informiranje, Izvješće Povjerenika za informiranje o provedbi Zakona o pravu na pristup informacijama za 2017. godinu, ožujak 2018.

Povjerenik za informiranje, Izvješće Povjerenika za informiranje o provedbi Zakona o pravu na pristup informacijama za 2016. godinu, ožujak 2017.

Povjerenik za informiranje, Izvješće Povjerenika za informiranje o provedbi Zakona o pravu na pristup informacijama za 2015. godinu, ožujak 2016.

Ured za udruge Vlade RH, Izvješće Ureda za udruge Vlade RH o provedbi savjetovanja sa zainteresiranom javnošću u postupcima donošenja zakona, drugih propisa i akata u 2018. godini. 


\section{Međunarodni pravni izvori}

\section{Europska unija}

Ugovor o Europskoj uniji i Ugovor o funkcioniranju Europske unije, 2012/C $326 / 01$

Direktiva 2003/4/EZ Europskog parlamenta i Vijeća od 28. siječnja 2003. o javnom pristupu informacijama o okolišu i stavljanju izvan snage Direktive Vijeća 90/313/EEZ

Direktiva 2003/35/EZ Europskog parlamenta i Vijeća od 26. svibnja 2003. o osiguravanju sudjelovanja javnosti u izradi određenih planova i programa koji se odnose na okoliš

Odluka Vijeća 2005/370/EZ od 17. veljače 2005. o zaključivanju, u ime Europske zajednice, Konvencije o pristupu informacijama, sudjelovanju javnosti u odlučivanju i pristupu pravosuđu u pitanjima okoliša

Uredba br. 1367/2006 Europskog parlamenta i Vijeća od 6. rujna 2006. o primjeni odredaba Aarhuške konvencije o pristupu informacijama, sudjelovanju javnosti u odlučivanju i pristupu pravosuđu u pitanjima okoliša na institucije i tijela Zajednice

Bijela knjiga o europskom upravljanju COM(2001)428 final

Opća načela i minimalni standardi za konzultiranje zainteresirane javnosti Mandelkernovo izvješće o boljoj regulaciji

\section{Ujedinjeni narodi}

Konvencija o pristupu informacijama, sudjelovanju javnosti u odlučivanju i pristupu pravosuđu u pitanjima okoliša (Aarhuška konvencija)

\section{Vijeće Europe}

Europska povelja o lokalnoj samoupravi (ETS No.122)

Protokol o pravu na sudjelovanje u poslovima lokalne vlasti uz Europsku povelju o lokalnoj samoupravi (CETS No. 207)

Preporuka Odbora Ministara o e-demokraciji CM/Rec(2009)1

Preporuka Odbora ministara o participaciji u lokalnom javnom životu Rec(2001)19

Kodeks sudjelovanja građana u odlučivanju

Smjernice za sudjelovanje javnosti u političkom odlučivanju 


\section{INTERNETSKE STRANICE}

https://esavjetovanja.gov.hr/ECon/Dashboard

https://www.proracun.hr/

https://www.hakom.hr/default.aspx

https://www.hera.hr/hr/html/index.html

https://www.ccaa.hr/hrvatski/naslovnica_l/

https://www.hnb.hr/

https://www.hzzo.hr/

https://europa.eu/european-union/index_hr

https://www.coe.int/hr/web/about-us

https://www.un.org/en/

https://www.oecd.org/

https://www.pristupinfo.hr/

https://udruge.gov.hr/

Internetske stranice 132 jedinice lokalne i regionalne samouprave (prema popisu u Prilogu 1) 
Prilog 1. Popis tijela uključenih u empirijsko istraživanje

\begin{tabular}{|c|c|c|c|}
\hline TDU i agencije & Gradovi & Općine & Županije \\
\hline $\begin{array}{l}\text { Ministarstvo } \\
\text { branitelja } \\
\text { Ministarstvo državne } \\
\text { imovine } \\
\text { Ministarstvo financija } \\
\text { Ministarstvo } \\
\text { gospodarstva, } \\
\text { poduzetništva i obrta } \\
\text { Ministarstvo } \\
\text { graditeljstva i } \\
\text { prostornog uređenja } \\
\text { Ministarstvo kulture } \\
\text { Ministarstvo } \\
\text { mora, prometa i } \\
\text { infrastrukture } \\
\text { Ministarstvo obrane } \\
\text { Ministarstvo } \\
\text { poljoprivrede } \\
\text { Ministarstvo } \\
\text { pravosuđa } \\
\text { Ministarstvo rada i } \\
\text { mirovinskog sustava } \\
\text { Ministarstvo } \\
\text { regionalnoga razvoja } \\
\text { i fondova Europske } \\
\text { unije } \\
\text { Ministarstvo turizma } \\
\text { Ministarstvo } \\
\text { unutarnjih poslova } \\
\text { Ministarstvo uprave } \\
\text { Ministarstvo za } \\
\text { demografiju, obitelj, } \\
\text { mlade i socijalnu } \\
\text { politiku } \\
\text { Ministarstvo zaštite } \\
\text { okoliša i energetike } \\
\text { Ministarstvo } \\
\text { zdravstva } \\
\text { Ministarstvo znanosti } \\
\text { i obrazovanja } \\
\text { Državna geodetska } \\
\text { uprava } \\
\text { Državna uprava za } \\
\text { zaštitu i spašavanje } \\
\text { Državni zavod } \\
\text { za intelektualno } \\
\text { vlasništvo }\end{array}$ & $\begin{array}{l}\text { Grad Bakar } \\
\text { Grad Beli Manastir } \\
\text { Grad Biograd na } \\
\text { Moru } \\
\text { Grad Bjelovar } \\
\text { Grad Buzet } \\
\text { Grad Cres } \\
\text { Grad Crikvenica } \\
\text { Grad Čakovec } \\
\text { Grad Delnice } \\
\text { Grad Dugo Selo } \\
\text { Grad Ivanec } \\
\text { Grad Karlovac } \\
\text { Grad Kastav } \\
\text { Grad Klanjec } \\
\text { Grad Koprivnica } \\
\text { Grad Kraljevica } \\
\text { Grad Krapina } \\
\text { Grad Lepoglava } \\
\text { Grad Ludbreg } \\
\text { Grad Makarska } \\
\text { Grad Mali Lošinj } \\
\text { Grad Novi Vinodolski } \\
\text { Grad Novska } \\
\text { Grad Ogulin } \\
\text { Grad Opatija } \\
\text { Grad Opuzen } \\
\text { Grad Osijek } \\
\text { Grad Ozalj } \\
\text { Grad Pazin } \\
\text { Grad Pula } \\
\text { Grad Rijeka } \\
\text { Grad Samobor } \\
\text { Grad Sinj } \\
\text { Grad Slunj } \\
\text { Grad Sveta Nedelja } \\
\text { Grad Šibenik } \\
\text { Grad Umag } \\
\text { Grad Varaždin } \\
\text { Grad Varaždinske } \\
\text { Toplice } \\
\text { Grad Velika Gorica } \\
\text { Grad Vinkovci } \\
\text { Grad Vrbovec } \\
\text { Grad Vrbovsko } \\
\text { Grad Vukovar } \\
\text { Grad Zadar } \\
\text { Gila }\end{array}$ & $\begin{array}{l}\text { Općina Baška } \\
\text { Općina Bedekovčina } \\
\text { Općina Bistra } \\
\text { Općina Brckovljani } \\
\text { Općina Brtonigla } \\
\text { Općina Cernik } \\
\text { Općina Čaglin } \\
\text { Općina Đulovac } \\
\text { Općina Generalski } \\
\text { Stol } \\
\text { Općina Gornji } \\
\text { Kneginec } \\
\text { Općina Gračišće } \\
\text { Općina Jarmina } \\
\text { Općina Jasenice } \\
\text { Općina Jelenje } \\
\text { Općina Kalnik } \\
\text { Općina Kamanje } \\
\text { Općina Kaptol } \\
\text { Općina Kistanje } \\
\text { Općina Kloštar Ivanić } \\
\text { Općina Kneževi } \\
\text { Vinogradi } \\
\text { Općina Konavle } \\
\text { Općina Kostrena } \\
\text { Općina Kraljevec na } \\
\text { Sutli } \\
\text { Općina Krapinske } \\
\text { Toplice } \\
\text { Općina Križ } \\
\text { Općina Lovran } \\
\text { Općina Ljubešćica } \\
\text { Općina Mače } \\
\text { Općina Marija Gorica } \\
\text { Općina Nijemci } \\
\text { Općina Nova } \\
\text { Bukovica } \\
\text { Općina Orle } \\
\text { Općina Pitomača } \\
\text { Općina Podgora } \\
\text { Općina Pokupsko } \\
\text { Općina Punat } \\
\text { Općina Rakovica } \\
\text { Općina Selnica } \\
\text { Općina Sibinj } \\
\text { Općina Sirač } \\
\text { Općina Starigrad }\end{array}$ & $\begin{array}{l}\text { Brodsko-posavska } \\
\text { županija } \\
\text { Karlovačka županija } \\
\text { Koprivničko- } \\
\text { križevačka županija } \\
\text { Krapinsko-zagorska } \\
\text { županija } \\
\text { Istarska županija } \\
\text { Varaždinska županija } \\
\text { Zagrebačka županija }\end{array}$ \\
\hline
\end{tabular}




\begin{tabular}{|c|c|c|c|}
\hline TDU i agencije & Gradovi & Općine & Županije \\
\hline $\begin{array}{l}\text { Državni zavod za } \\
\text { mjeriteljstvo } \\
\text { Državni zavod } \\
\text { za radiološku i } \\
\text { nuklearnu sigurnost } \\
\text { Hrvatska agencija za } \\
\text { civilno zrakoplovstvo } \\
\text { - HACZ } \\
\text { Hrvatska agencija za } \\
\text { nadzor financijskih } \\
\text { usluga - HANFA } \\
\text { Hrvatska energetska } \\
\text { regulatorna agencija - } \\
\text { HERA } \\
\text { Hrvatska narodna } \\
\text { banka - HNB } \\
\text { Hrvatska regulatorna } \\
\text { agencija za mrežne } \\
\text { djelatnosti - HAKOM } \\
\text { Hrvatski zavod } \\
\text { za zdravstveno } \\
\text { osiguranje - HZZO }\end{array}$ & $\begin{array}{l}\text { Grad Zagreb } \\
\text { Grad Zlatar }\end{array}$ & $\begin{array}{l}\text { Općina Tompojevci } \\
\text { Općina Trnovec } \\
\text { Bartolovečki } \\
\text { Općina Tučepi } \\
\text { Općina Velika Ludina } \\
\text { Općina Veliko } \\
\text { Trgovišće } \\
\text { Općina Viškovo } \\
\text { Općina Vojnić }\end{array}$ & \\
\hline
\end{tabular}


Summary

Petra Đurman*

\section{PUBLIC CONSULTATIONS IN THE REGULATORY PROCESS IN CROATIA}

Public consultations today represent a common instrument for public participation in the regulatory process, that is, in the process of formulating public policies, including draft laws, secondary legislation and other acts. Although public consultations are most often legally regulated, there are differences in the nature, scope and content of the pertinent legal requirements, which - alongside administrative tradition and established practices - reflect on their implementation in practice. In Croatia, public consultations - now in the form of e-consultations - represent a rather new instrument for involving the public in the regulatory process, the features and outcomes of which have not been widely scientifically investigated yet. Therefore, the purpose of this paper is twofold; first, to analyse the legal framework for public consultations and its compatibility with the standards contained in legal acts and documents of the European Union, Council of Europe and other international organizations (UN, OECD). Secondly, the paper aims at providing empirical insights into the implementation of e-consultations in the practice of administrative organizations at different levels of government (national, regional, local). Empirical research has been conducted by a quantitative content analysis of the reports and other documents of the e-consultations implemented in the period from 2016 to 2018. The findings suggest that although the legal framework for public consultations is adequate and compatible with international standards, there are some deficiencies with regard to their practical implementation, such as the frequency of their conduction at the local level, the clarity of the process, etc.

Keywords: public consultations; legal framework; implementation of e-consultations; administrative organizations; empirical research

* Petra Đurman, Ph. D., Postdoctoral Researcher, Faculty of Law, University of Zagreb, Trg Republike Hrvatske 14, 10000 Zagreb, Croatia; pdurman@pravo.hr;

ORCID ID: orcid.org/ 0000-0002-8287-3686 